
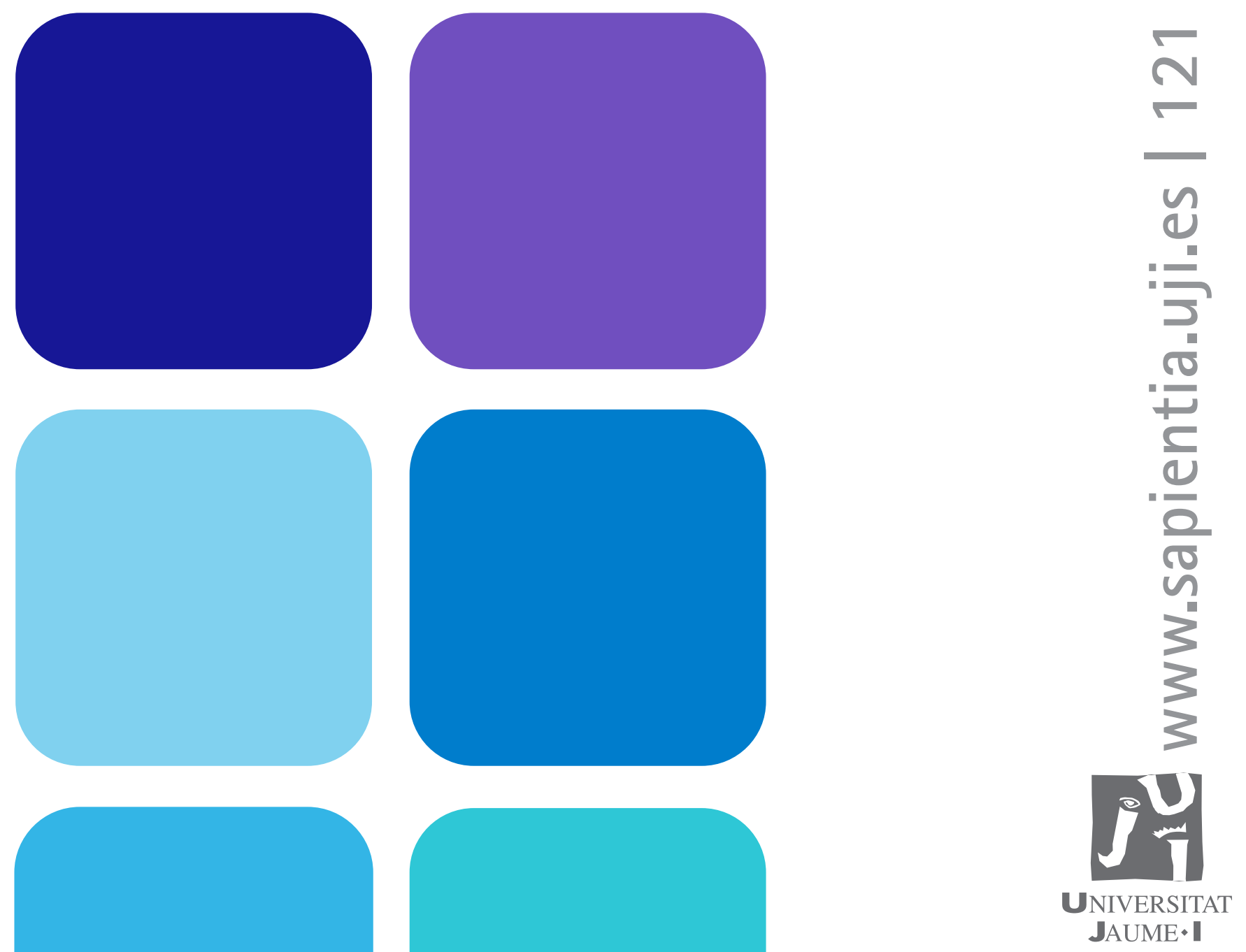

\title{
Gestió de la diversitat cultural en contextos socioeducatius
}




\section{Gestió de la diversitat cultural en contextos socioeducatius}

Auxiliadora Sales Ciges

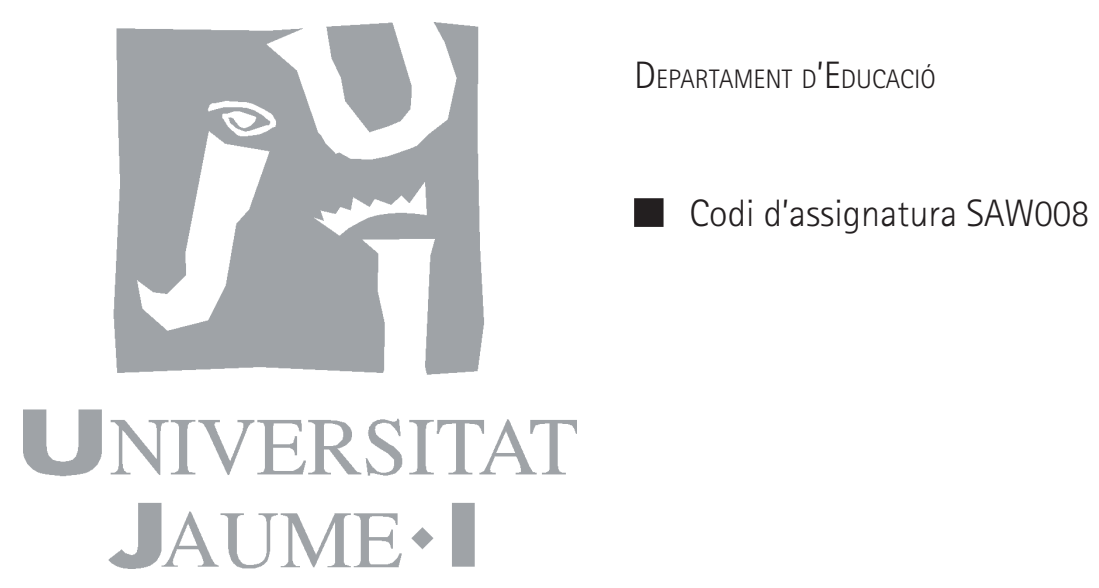


Edita: Publicacions de la Universitat Jaume I. Servei de Comunicació i Publicacions Campus del Riu Sec. Edifici Rectorat i Serveis Centrals. 12071 Castelló de la Plana http://www.tenda.uji.es e-mail: publicacions@uji.es

Col·lecció Sapientia 121

www.sapientia.uji.es

Primera edició, 2016

ISBN: 978-84-16356-96-6

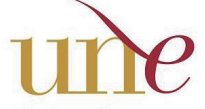
UNÍ́N DE EDTTORIALES
UnTERStTARIAS EspaÑoLAs
Publicacions de la Universitat Jaume I és una editorial membre de l'UNE, cosa que en garanteix la difusió de les obres en els àmbits nacional i internacional. www.une.es

\section{cc) (†) ()}

Reconeixement-CompartirIgual

CC BY-SA

Aquest text està subjecte a una llicència Reconeixement-CompartirIgual de Creative Commons, que permet copiar, distribuir i comunicar públicament l'obra sempre que s'especifiquen l'autoria i el nom de la publicació, fins i tot amb objectius comercials, i també permet crear obres derivades, sempre que siguen distribuïdes amb aquesta mateixa llicència. http://creativecommons.org/licenses/by-sa/3.0/legalcode

Aquest llibre, de contingut cientific, ha estat avaluat per persones expertes externes a la Universitat Jaume I, mitjançant el mètode denominat revisió per iguals, doble cec. 


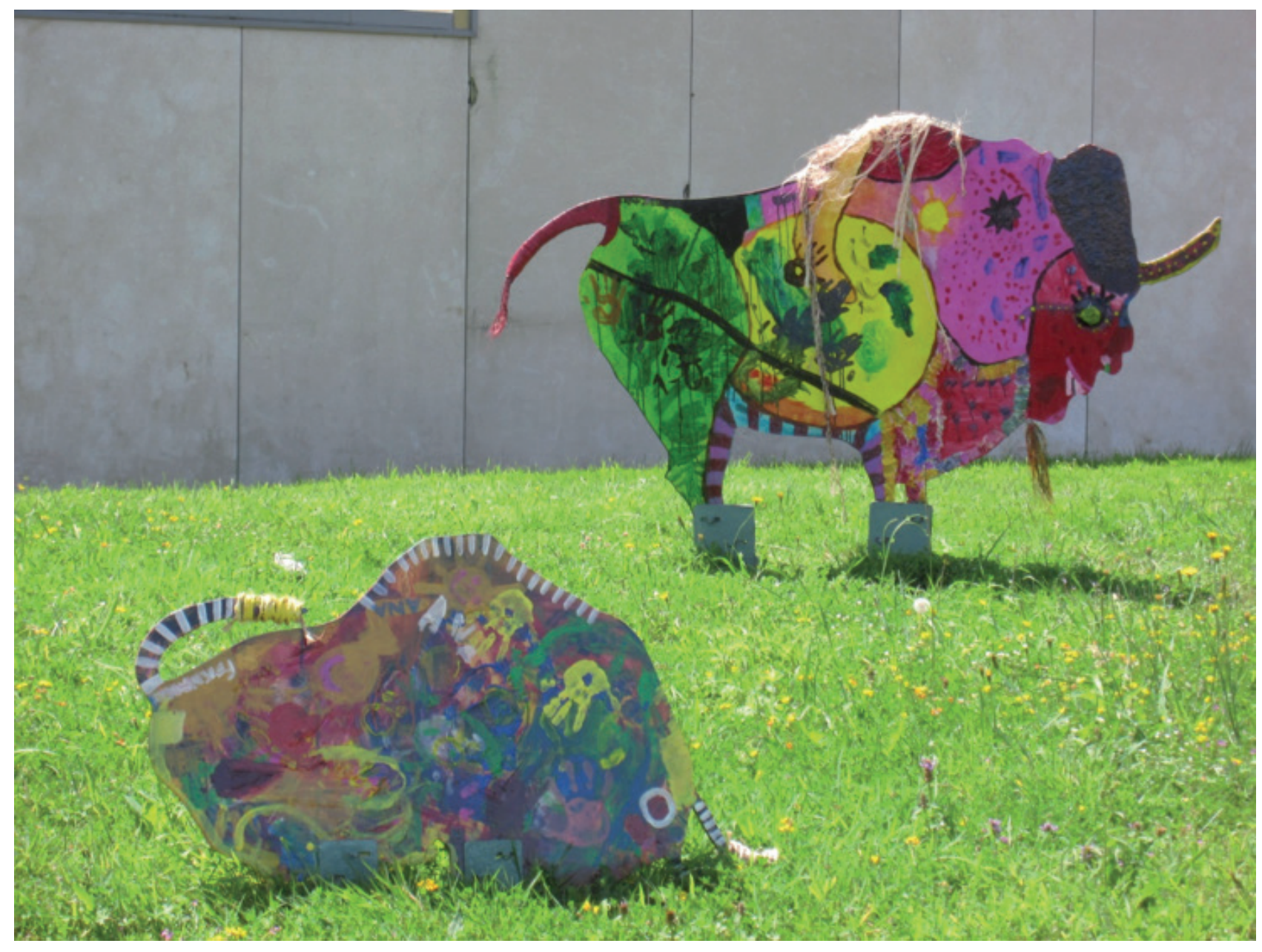




\section{ÍNDEX}

Introducció

Tema 1. Cultura, diversitat i educació. L'intercultural com a mirada educativa.......... Introducció

1.1. Gestió de la diversitat cultural a la societat de la informació: enfocament intercultural.

1.1.1. Societat complexa, mirades híbrides i mestisses

a) De la cultura a la culturalitat....

b) Identitat cultural i racisme

c) Diversitat, diferència i desigualtat

1.1.2. Mirada intercultural inclusiva: dues cares del mateix enfocament

1.2. Models i polítiques educatives de gestió de la diversitat cultural.

1.2.1. Model assimilacionista i política de compensació

1.2.2. Model integracionista des de la política de compensació i relacions humanes

1.2.3. Model Pluralista i política d'estudi de grup.

1.2.4. Model i política intercultural.

1.2.5. Educació intercultural: un model per abordar la diversitat Activitats de reflexió-acció

Lectures recomanades

Tema 2. Contextos socioeducatius interculturals: com ens organitzem?

Introducció

2.1. Com aprenem del context? Elements clau per comprendre i millorar

el nostre entorn

2.1.1. Aprendre en situació

2.1.2. Analitzar el context socioeducatiu i transformar-lo

a) Anàlisi semiòtic. Pedagogies invisibles dels espais

b) Investigació-acció participativa i mirada etnográfica

c) Guia CEIN: una eina d'autoavaluació

2.2. Ciutadania crítica i educació intercultural: moviments

de transformació social

2.2.1. El canvi que ve a partir del que som....

2.2.2. Desenvolupant cultura col-laborativa: canvis organitzatius

2.2.3. Construïm ciutadania canviant les nostres pràctiques

Activitats de reflexió-acció

Lectures recomanades 
Tema 3. Pràctiques interculturals: prejudicis, comunicació i relacions quotidianes

Introducció

3.1. Eliminant prejudicis. Programes de formació d'actituds interculturals

3.1.1. Programes de formació d'actituds interculturals

3.2. Comunicació intercultural i multilingüisme.

3.2.1. Modalitats d'educació bilingüe

3.3. Gènere, cultura i classe social en les relacions quotidianes

Activitats de reflexió-acció

Lectures recomanades 


\section{Introducció}

Aquest material planteja el tractament educatiu de la diversitat cultural en el context socioeducatiu. La diversitat és un aspecte de la realitat de la societat de la informació que hem de considerar a l'hora de planificar i desenvolupar la nostra tasca educativa com a professionals en un món globalitzat.

Si volem que la diversitat cultural siga un recurs enriquidor i no considerar-lo com un problema que obstaculitza el procés d'ensenyament-aprenentatge, hem de canviar la nostra mirada cap a l'educació des d'un enfocament intercultural. Per això, tractarem d'analitzar els conceptes bàsics $i$ les diferents perspectives actual per abordar la diversitat cultural i quines són les implicacions pedagògiques d'aquests enfocaments socials i polítics.

Així, una vegada coneguem les característiques, les dimensions i els factors socioeducatius que condicionen la intervenció educativa, aprofundirem en les estratègies pedagògiques que afavoreixen una dinàmica democràtica, oberta, flexible $\mathrm{i}$ respectuosa amb la diversitat des de la igualtat.

Els destinataris d'aquest material són els professionals de l'educació (mestres, pedagogs, psicopedagogs i educadors socials) amb la intenció d'ajudar-los a analitzar críticament les implicacions pedagògiques de la interculturalitat, els models de gestió de la diversitat i les eines per llegir els contextos socioeducatius. Tot això amb l'objectiu de formar professionals reflexius i transformadors, que sàpien desenvolupar projectes educatius innovadors amb mirada intercultural de manera col·laborativa.

El contingut està estructurat en tres temes o blocs temàtics que recullen el temari general de l'assignatura «Gestió de la diversitat cultural en contextos socioeducatius», que dóna nom també a aquests materials docents.

La proposta d'activitats inclosa en cada tema està directament relacionada amb els resultats d'aprenentatge de l'assignatura, ja que se centra en:

a) Reflexió individual sobre la pròpia autobiografia i la construcció de la identitat cultural i la gestió de la diversitat en el context més immediat.

b) Anàlisi crítica de les implicacions pedagògiques dels diferents models de gestió de la diversitat cultural.

c) Desenvolupament de propostes d'intervenció interculturals complexes, des de l'anàlisi del context, la detecció de necessitats, la planificació i posada en marxa de l'acció, i l'avaluació del procés i propostes de millora. 


\section{TEMA 1}

\section{Cultura, diversitat i educació. L'intercultural com a mirada educativa}

\section{Introducció}

El tema 1 té com a objectiu en un primer punt, aclarir els conceptes bàsics de l'assignatura, com ara cultura, diversitat cultural, interculturalitat. S'hi revisen els conceptes que l'educació incorpora d'altres disciplines com ara l'antropologia, la sociologia, la psicologia social i els estudis culturals. Ens permet situar la gestió de la diversitat cultural en el marc de la societat del segle XIX globalitzada i mestissa, de manera que s'hi reubiquen els gran debats educatius sobre universalitat $\mathrm{i}$ relativisme des del paradigma de la interculturalitat.

A partir d'aquest marc de reflexió, el segon apartat del tema fa una descripció dels diferents models de gestió de la diversitat cultural tant des del plànol de la política educativa com des de la resposta social i pedagògica que es dóna en diferents contextos socioeducatius: institucions educatives i contextos informals d'aprenentatge. Es fa un repàs des del model assimilacionista, passant per l'integracionista, pluralista fins a arribar a l'intercultural. Aquesta classificació dels models ens permet reconèixer la conceptualització de la diversitat i els objectius educatius i socials que fonamenten les diferents polítiques i programes educatius que es desenvolupen sota el que, en molts casos, s'anomena educació intercultural. Una revisió crítica sobre els diferents models ens permet, com a professionals de l'educació i de la psicopedagogía, identificar els factors i els elements bàsics que caracteritzen una proposta educativa respectuosa amb la diversitat, i basada en la igualtat d'aquelles que reprodueixen prejudicis i perpetuen desigualtats en nom de la diferència.

\subsection{Gestió de la diversitat cultural en la societat de la informació: enfocament intercultural}

\subsubsection{Societat complexa, mirades híbrides i mestisses}

El repte que la diversitat planteja a l'educació és l'exigència de possibilitar l'accés de tot l'alumnat a una escola de qualitat que els prepare per a la participació democràtica en un món complexe diferenciat i assincrònic (McCarthy, 1994; 
Abdallah-Pretceille, 2001). Això suposa la revisió de les grans finalitats i principis de la modernitat (i de la idea d'educació com a instrument útil per a la igualtat), la qual cosa ens acosta més a actituds de radicalització de la democràcia que no pas a actituds postmodernes que amaguen el fenomen de la desigualtat, $i$ aillen la diversitat del seu component social (Ayuste i altres, 1999).

Els processos de canvi han d'emmarcar-se en el pas d'una societat que ha deixat de ser predominantment industrial i ha passat a caracteritzar-se com una nova societat de la informació, la comunicació i el coneixement. És una època de fragmentació social (Bauman, 2008) i, al seu torn, de reconeixement de la pluralitat, en la qual es qüestionen les contradiccions del projecte de la modernitat i que ens instal·la en una societat del risc (Beck, 2002), la fragilitat i la provisionalitat. No és que es puga qüestionar la diversitat, ja estructural, sinó que l'intent per integrar-la en les estructures preexistents fracassa. Per aquest motiu, la metàfora de la xarxa ens apropa a un model social més comunitari, que té com a referent, un model ètic de mínims, que ens porta a establir relacions de confiança i suport entre ciutadans, en un espai social públic en els quals compartir objectius que aporten un benefici comú (Essomba, 2006).

En aquesta complexa realitat hem d'aprendre a conviure junts, entre la pressió de les xarxes que ens instrumentalitzen i les comunitats que ens tanquen i ens incomuniquen (Touraine, 1997). Per això, els professionals de l'educació hem de reflexionar i actuar pel foment del diàleg intercultural, de manera que les nostres actituds, estratègies $i$ interrelacions en la tasca educativa reflectisquen el compromís ciutadà de transformar el context social i escolar cap a la interculturalitat i la inclusió.

Suposa, doncs, en aquesta societat mestissa, la necessitat d'afavorir el desenvolupament d'una identitat cultural oberta i flexible. De fet, no solament tota societat és multicultural, sinó que tots i cadascun de nosaltres creem la nostra pròpia identitat cultural a partir de la nostra interacció amb diferents grups culturals: som el resultat de moltes i diverses influències (McCarthy, 1994). Per tant, més que parlar de diferents cultures, hauríem de reconèixer l'altre com a persona i parlar de culturalitat, com a dinàmiques, processos, mescles i transformacions que es produeixen en les actuals situacions de pluralitat cultural. Hem d'aprendre a pensar en un món híbrid, on la identitat cultural es dóna en un context intersubjetiu i és producte de relacions i raonaments, en els quals es produeixen constants fractures, mestissatges i camins creuats. Aquesta és la cultura de la diversitat i aquest és l'enfocament intercultural de l'educació: la mirada en els processos complexos, en l'imprevisible, en la negociació i la creació contínua (Abdallah-Pretceille, 2001).

\section{a) De la cultura a la culturalitat}

Un dels conceptes més ambigus i profusament definits des de l'antropologia és el de cultura. Una concepció d'acord al caràcter transformador de l'educació és la de cultura com a dinàmica i oberta, ja que l'ésser humà és un animal inserit en trames de significació que ell mateix ha teixit (Geertz, 2000). La cultura es concep com el 
conjunt de representacions i normes de comportament que contextualitzen la rica, canviant i creadora vida dels membres d'una comunitat i que es va ampliant, enriquint i modificant com a conseqüència precisament del dinamisme i la innovació d'aquells que actuen sota el paraigües de la seua influència (Pérez Gómez, 1993). Es refereix al conjunt de relacions que l'ésser humà estableix amb si mateix, amb els altres éssers humans i amb la naturalesa, resultat tant del tipus de formació que rep, com del conjunt d'accions que realitza. Per això, ofereix sempre un espai de negociació de significats i es recrea constantment com a conseqüència d'aquest mateix procés de negociació.

Dins dels components del concepte de cultura, podem distingir entre cultura $o b$ jectiva, com tot element visible i tangible d'un grup particular (artefactes, vestits, menjars, etc.), i cultura subjectiva, referida a allò no tangible, a l'invisible, com ara els valors, les normes de comportament, els rols, les actituds i les cosmovisions. Encara que aquesta segona dimensió de la cultura és més difícil d'analitzar i d'investigar, perquè generalment està implícita, resulta ser la part més potent $\mathrm{i}$ poderosa d'aquesta, i el punt d'interès principal per desenvolupar l'enteniment intercultural, ja que fins i tot dins d'una mateixa societat coexisteixen diferents grups que tenen cultures subjectives diferents: diferent sistema de valors, normes de conducta, models d'interacció, pràctiques de socialització i patrons lingüístics diversos, que són els components de la cultura que provoquen la majoria de les incomprensions interculturals i els problemes de comunicació (Cushner,1992).

Sense desestimar la importància que tenen els elements materials de la cultura, considerem que el que diferencia més profundament uns grups culturals d'uns altres és, sobretot, el conjunt de significacions o interpretacions apreses que apliquen sistemàticament als estímuls del seu entorn i les actituds, valors, representacions i conductes que comparteixen i que tracten de transmetre.

Un canvi de caracterització de la cultura com a dinàmica, complexa, inacabada $\mathrm{i}$ canviant és fonamental per desterrar de l'educació la tradicional percepció de la cultura com a estàtica, immutable i fragmentada. És important reconèixer la capacitat que els membres d'una cultura tenen per reinterpretar i renegociar els seus valors i significats en un constant procés de recreació, la qual cosa significa que la cultura no té vida pròpia al marge dels individus que la desenvolupen (AbdallahPretceille, 2001).

Per tant, el que millor defineix la cultura són els processos de barreja, mestissatge, transgressió que es donen mitjançant les relacions entre individus i grups. En aquest sentit, el canvi, la transformació intrínseca al procés cultural, s'entén millor des de la idea de culturalitat que ens proposa Martine Abdallah-Pretceille (2006) perquè ens remet als processos de complexització, heterogeneïtzació creixent del teixit social i fragmentació dels elements culturals, que ens fa portar la mirada cap als intersticis, les esquerdes i els espais imprevisibles de les interaccions humanes.

Així doncs, més que una mirada culturalista, necessitem una mirada intercultural que es fixe i analitze aquest procés constant de negociació de significats per construir 
sabers compartits, que ens fa preguntar-nos per la identitat pròpia en relació als altres. La mirada intercultural es focalitza en les maneres en què cadascú utilitza els trets culturals per dir i dir-se, per expressar-se verbalment, corporalment, socialment, personalment. No pretén aprehendre la cultura com un tot, sinó que suposa el «coneixement gradual d'elements significatius», amb un saber parcial, depenent del context i de l'acció de les persones (Abdallah-Pretceille, 2006). Tracta de comprendre situacions complexes, imprevisibles, subjectives i canviants, on la cultura s'entén com a acte i no com a objecte. Com diu Schutz (1987:219):

el model cultural del grup no és un lloc de refugi, sinó un camp d'aventura, no una evidència, sinó un punt d'interrogació per investigar, no una eina útil per aclarir les situacions embolicades, sinó una situació problemàtica i fins i tot difícil de dominar.

Caldria fer una menció especial al concepte raça, per la confusió que en moltes ocasions genera en l'àmbit educatiu, atès que dóna peu a la polèmica relació entre les diferències biològiques i culturals, i sobretot tenint en compte que al llarg de la història les fronteres culturals, geogràfiques i físiques entre els grups racials s'han fet difuses i no permeten parlar de races biològicament «pures». Des del camp de l'antropologia física és un terme molt desprestigiat al ser utilitzat a les relacions humanes, que no són interaccions zoològiques sinó socials i culturals, en les quals els components biològics són analizats i interpretats des d'un context de valors socials. Per tot 1'anterior, quan parlem de racisme, ens referim a actituds, creences i comportaments apresos històricament en el propi grup de referència sobre les relacions interètniques, que no només concerneixen a l'aspecte biològic, sinó també a altres trets diferenciadors de caràcter cultural, ètnic o social (Calvo Buezas, 1990; 1995).

L'evolució del concepte de raça i del terme racisme ha plantejat la distinció entre un «racisme clàssic»» o tradicional i un altre de «simbòlic». El primer es basa en l'argument biològic etnocentrista que els altres grups són racialment inferiors i per això no poden gaudir dels mateixos drets que el propi grup, mentre que el simbòlic argumenta que la discriminació ja no existeix i que les minories estan fent injustificades demandes per canviar l'status quo. S'argumenta que aquests grups obtenen més del que es mereixen en la societat i haurien d'aconseguir-ho per si mateixos, ja que se'ls ofereixen unes oportunitats col·lectives que es neguen al grup majoritari. Aquest tipus de racisme es basa en el rebuig d'altres grups referit a allò moral i no tant a allò racial. De fet, moltes persones que simpatitzen amb les víctimes de passades injustícies, i que no es consideren prejuiciosos o discriminatoris, posseeixen sentiments i creences negatius cap als grups minoritaris (Ponterotto i Pedersen, 1993).

Aquests dos tipus de racisme poden donar-se: en l'àmbit individual, quan és expressat per aquests i també en l'àmbit institucional, quan s'afavoreix des de les institucions la manipulació o la tolerància intencionada o no intencionada de polítiques que restringeixen injustament les oportunitats de certs grups, i legitimen així la discriminació des del propi estat (Hawkins, 1991). 
Això ens porta a parlar de la identitat cultural, que en realitat és molt més elàstica $\mathrm{i}$ relativa del que ens pensem i la volem pensar. Està formada per elements i atributs de la més variada procedència $\mathrm{i}$ canvia de manera dinàmica com la pròpia cultura.

El desenvolupament de la identitat cultural implica l'autoconcepte o autoimatge com una estructura central del desenvolupament humà que es va formant mitjançant la interacció del subjecte amb el seu entorn, i defineix la manera en què es veu a si mateix i el perceben els altres (Lay, 1992). Des de l'interaccionisme simbòlic s'explica la formació de la individualitat autoconscient a través de la successiva adopció dels papers de les persones que ens envolten des dels nostres primers anys. Aquests rols es van interioritzant dins del procés social, fora del qual la persona no té sentit. Així es construeix el «jo» gràcies a «l'altre»:

No podem realizar-nos a nosaltres mateixos sinó en el grau en què reconeguem l'altre en la seua relació amb nosaltres. Només quan adopta l'actitud de l'altre, pot l'individu realizar-se a si mateix com a persona (Mead, 1972: 220).

Però, qui és l'altre? Diu Teresa San Román (1996) que l'altre en realitat no existeix per a nosaltres, és una entitat abstracta, ignorada i desconeguda, que ens serveix per pensar en nosaltres mateixos i fer-nos autocrítics. Però l'altre és concret, són molts altres i variats, i hem de construir les nostres identitats en interacció i negociació amb ells.

Es més, la identitat ètnica, com a poble, permet la variació al si de la pròpia cultura i culturalment adopta i selecciona els trets que simbolitzaran la diferència. Per tant, diu San Román (1996), la cultura no fa la identitat, és la identitat adquirida històricament la que selecciona quins aspectes de la seua cultura representaran més adequadament la seua diferència i unicitat. Per exemple, poden ser símbols identitaris elements culturals com el nomadisme en els gitanos, fins i tot quan fa segles que la majoria d'ells no es mouen, com és el cas espanyol, en contraposició al nostre marcat arrelament a la terra.

No hauríem de parlar de diferències entre cultures en termes holistes i començar a parlar de fets culturals concrets. Una cultura ni una identitat ètnica no desapareix perquè es modifique o desaparega un fet cultural.

Hem de tenir en compte que qualsevol que es percep a si mateix com a part d'una història, ancentres, tradició i objectiu polític compartit es pot considerar grup ètnic, però curiosament, el qualificatiu d'ètnic, tal com fan els mitjans de comunicació, serveix per ser assignat únicament a produccions culturals considerades premodernes o extramodernes. I així, diu Delgado (1998), una dansa sufí o un restaurant peruà són «ètnics», però un vals o una pizzeria, no.

Vigilem que la noció de minoria ètnica finalment no «etnifique» el grup, és a dir, que acabe indicant l'existència d'una mena de minusvalidesa cultural premoderna (Delgado, 1998). 
Al cinema també podem tenir l'exemple: Rey Chow (1999) va analitzar pel·lícules com ara El Club de la Bona Estrel·la, i apunta que quan els escriptors o els guionistes fan històries sobre els blancs, ningú diu que siguen obres ètniques o sobre un grup cultural determinat, és una història i punt. Rey Chow es pregunta per què es consideren «ètnics» els escriptors i escriptores afroamericans, asiàtics, gitanos, etc., mentre que no sentim a parlar dels origens ètnics i les sensibilitats ètniques d'actors i escriptors famosos (dels EUA) que són blancs.

L'exemple d'El Club de la Bona Estrel·la, com d'altres pel·lícules diferenciades com a ètniques, compleixen una funció pedagògica, es a dir, que «els altres» estan tractant de redescobrir els seus orígens xinès, japonès, africà, llatí, etc., i que són esencialment diferents de la línia base, normativa i ben coneguda, representada per hòmens $\mathrm{i}$ dones blancs.

La interrogació invisible que s'amaga darrere els aparells del «caràcter ètnic» multiculturalista és: «fins a quin punt ets autèntic?».

Es tracta, doncs, d'un èmfasi en la diferencia que ens porta a un neoracisme. El nou racisme, és un racisme heteròfil en algun sentit, perquè fa un elogi a la diferència cultural, potencia «les arrels» de cada poble. Hi ha un racisme biologicista jeràrquic, però també un racisme diferencialista separador de caràcter culturalista (San Román, 1996).

De vegades, les pròpies propostes multiculturalistes de reconeixement dels drets de les «minories ètniques» han produït finalment efectes perversos, per aquesta noció essencialista i mística de cultura i per l'intent de crear i reconèixer segments clarament diferenciats de la població, en una divisió artificial. Com diu Manuel Delgado (1998), fins i tot dividir el jovent en tribus urbanes produeix l'etnifiació artificial de la població no exòtica en aquest cas, però sí conflictiva.

Quan el racisme biologicista dóna pas al culturalista es canvien també els marcadors de la diferència. Abans era el color de la pell (considerat com un marcador físic dur, permanent) ara s'ha substituït per marcadors culturals més blanets (no físics o no permanents) però que es defensen com a inalterables, i que s'endureixen per marcar diferèncias deterministes.

No es discrimina el diferent sinò el que per alguna raó es categoritza com a diferent a partir de l'ús d'algún marcador (San Román, 1996). Els eufemismes políticament correctes amaguen realitats molts més dures i políticament incorrectes.

Des de Margaret Mead es va imposar als mitjans antiracistes no dir, per exemple, negre o blanc, de la mateixa manera que els educadors d'educació especial i terapèutica fugen d'un terme a un altre (de subnormal a deficient, de deficient, etc.), o ho fan els gerontòlegs (de vell a ancià, de tercera edat a persona gran...) per intentar fugir del malefici d'un concepte ben difícil d'expressar sense molestar a ningú (San Román, 1996: 170).

D'igual manera, es van buscant diferents maneres d'utilitzar els termes, amagant el que en realitat perdura darrere del seu ús. Com diu de nou Teresa San Román (1996: 171): 
[...] no veig res clar anomenar racisme qualsevol forma d'alterofòbia que no considera «raça» per a res. En segon lloc evitaria canviar constantment els termes per fugir dels problemes de concepte. Si es connota i es passa a utilitzar ètnia pels racistes per dissimular, acollint-se a l'ús d'etnicitat (cultura + identitat de poble), per a l'antropologia aquest últim terme queda al seu torn «contaminat». Llavors ho substituïm, per exemple, per cultura, que no és el mateix que volia dir-se amb etnicitat i, a més, els racistes comencen immediatament a anomenar altres cultures, com nosaltres, tots els que abans anomenaven races. És una «retorsió terminológica».

c) Diversitat, diferència i desigualtat

Davant la complexitat de les societats i les identitats, l'educació i la cultura s'entenen com a processos necessàriament inacabats, que requereixen una constant labor de reflexió i d'anàlisi de la realitat diversa i plural. Es tracta d'un projecte global davant el qual no hi ha una percepció unàmine, ja que la complexitat i la pluralitat socials fan que els significats i les expectatives que els diferents grups culturals i sectors socials atorguen a l'educació siguen molt diversos i, en ocasions, contraposats (Torres González, 1999).

Partint dels conceptes dinàmics i oberts d'educació i cultura, en el context de l'escola, trobem el tercer vèrtex d'aquest triangle, el concepte de diversitat, concebuda com la qualitat intrínseca que tenen els múltiples éssers i objectes del nostre entorn. La diversitat, per tant, és una característica de singularització de cada ésser viu, però hi donem una gran càrrega ideològica, ja que som nosaltres els que creem la diferència mitjançant la valoració (positiva o negativa) d'aquesta diversitat (Carbonell, 1996).

Com apunten Jiménez i Vilà (1999:28): «la diversitat és una característica intrínseca a la naturalesa humana i una possibilitat per a la millora i l'enriquiment de les condicions i les relacions socials i culturals entre les persones i entre els grups socials».

Hem de, distingir, doncs entre els conceptes de diversitat, diferència i desigualtat, ja que axiològicament tenen implicacions molt diferents. En paraules de Manuel Delgado (1998:25) diguem que:

la diferència no és desigualtat, ni igualtat implica uniformitat ni unanimitat. Els elements d'un sistema no s'interrelacionen i cooperen malgrat ser diferents, sinó exactament al contrari: perquè són diferents. D'una banda, el dret a la diferència, és a dir, el dret de cada individu i de cada comunitat a creure's diferent dels altres, i dotar de continguts aquesta voluntat de diferenciació, suposa, d'altra banda, el dret a la igualtat, o siga, el dret d'aquells al fet que siguen acceptats com són a ser indistiguibles davant la lluita per la justícia.

De fet, com continua Manuel Delgado (1998:129): «Els ciutadans no només tenen la diversitat cultural al seu voltant, sinó també dins d'ells mateixos»: gènere sexual, classe social, cognoms, lloc de naixement, barri, gustos musicals o literaris, estudis, interesos, llengua... 
Des d'ací creiem que la relació entre el dret a la diferència i el dret a la igualtat, queda perfectament expressat per Teresa San Román (1996:140) quan assenyala que:

aquest dret a la diferència a mi em sembla que només pot significar dret a comptar amb recursos igualitaris per promoure la pròpia diferència en un marc de drets generals consensuats als quals se subordina.

Per això, diem que la diversitat, en condicions d'igualtat, és tolerable i fins i tot desitjable; la desigualtat ha de ser corregida si hem d'admetre la universalitat del dret a l'educació. No són, per tant, tolerables les diferències que suposen desigualtats entre individus o entre grups. De fet, pot resultar problemàtic definir el camí cap a la igualtat recorregut pel procés d'escolarització, però la veritat és que la seua inexistència o les seues deficiències condueixen amb més seguretat cap a un augment de la desigualtat. Així ho expressa amb encert Gimeno Sacristán (2000:63):

L'educació proporcionada per l'escolarització obligatòria, igual per a tots, constitueix un requisit que capacita per a l'exercici de la ciutadania plena. El dret social a la cultura i a l'educació té caràcter fonamental, no solament perquè d'aquest depèn la dignificació humana, per poder enriquir les possibilitats del seu desenvolupament, sinó que ho és perquè s'entrellaça amb altres drets civils, polítics i econòmics de les persones, i les capacita per a l'exercici d'aquests, ja que els possibilita i els potencia.

I és, justament, el dret a la cultura el que fonamenta la reivindicació a exercir-ho respecte a una determinada opció cultural, atenent a les diferències en les quals s'assenta la identitat personal.

\subsubsection{Mirada intercultural inclusiva: dues cares del mateix enfocament}

Cal que la interculturalitat i la inclusió combinen els seus esforços i reivindicacions, tant a favor de la diversitat com bé en demanda d'igualtat i educació de qualitat per a tothom. Si realment creiem que la diversitat concerneix a tots i que l'objectiu principal d'ambdues és la igualtat en la diversitat, trobem un camí comú a recórrer.

Juntes advoquen per un enfocament que amplie els límits de la normalitat fins a afirmar que el normal és la diversitat i que aquesta és positiva i enriquidora, si es cuiden les condicions de justícia social que no convertisquen les diferències en desigualtats. I l'aspecte en el qual crec que conflueixen els plantejaments inclusiu i intercultural sobre el tractament de la diversitat, no és tant en el concepte de necessitats educatives especials, que pot continuar sent enganyós, sinó en el paper que l'educació ha de jugar en l'atenció a aquesta diversitat que som tots. La diversitat no concerneix a un reducte «especial»o «diferent» de persones, sinó que és un assumpte de tots $\mathrm{i}$, per tant, una responsabilitat col·lectiva i institucional. No és una qüestió de voluntarisme, bones intencions, pegats o afegits curriculars, sinó que requereix una reforma total, tant política com pedagògica, del sistema educatiu (Besalú, 2002). Cal donar 
resposta a les diferències des d'un marc democràtic d'igualtat d'oportunitats, per tant, no estem parlant només de valors i actituds personals sinó de drets ciutadans que tots, pel fet de ser éssers humans, tenim (Echeíta i Ainscow, 2011).

S'evidencia una crisi de valors (contradiccions, tensions, dilemes, reptes) en el món de l'educació pel que fa a les idees i valors de la modernitat, i que donen origen a un discurs crític postmodern (lliure economia, escepticisme, relativisme, individualisme, consumisme, ahistoricisme, etc.) (Pérez Gómez, 1993). Per tant, el gran repte educatiu consisteix a trobar l'equilibri entre la igualtat i la diversitat, $i$ es qüestiona el context social en què se circumscriu. Davant aquests canvis vertiginosos i la crisi axiològica, és necessari reprendre la modernitat i radicalitzar els seus objectius més democràtics i igualitaris, mitjançant models educatius inclusius $\mathrm{i}$ interculturals.

D'aquesta manera, davant la «invisibilitat» homogeneïtzant que es deriva dels enfocaments educatius assimilacionistes, es tractaria d'afavorir la «invisibilitat» que proporciona el dret a l'anonimat, a ser un ciutadà més, sense haver de justificar-se constantment. Davant la «visibilitat» etiquetadora dels programes compensatoris, hauríem de promoure la visibilitat de la diversitat en totes les seues dimensions socioculturals, des de la lliure elecció de la identitat cultural de cada persona i comunitat, que puga mostrar-la i reconèixer-la públicament sense sentir-se humiliada o menyspreada. És a dir, hem de conjugar la igualtat de drets amb el dret a la diferència. En lloc d'assenyalar la diversitat estereotipant-la. Cadascú ha de triar el contingut de la seua diferència, ja que som pluriidentitaris i les discriminacions es poden donar en totes les dimensions (sexe, cultura, classe social, capacitat, edat...).

Podem veure gràficament com el significat d'aquests dos conceptes varia en funció de l'enfocament ideològic i educatiu des del qual es planteja i desenvolupa (Sales Ciges, 2002:67).

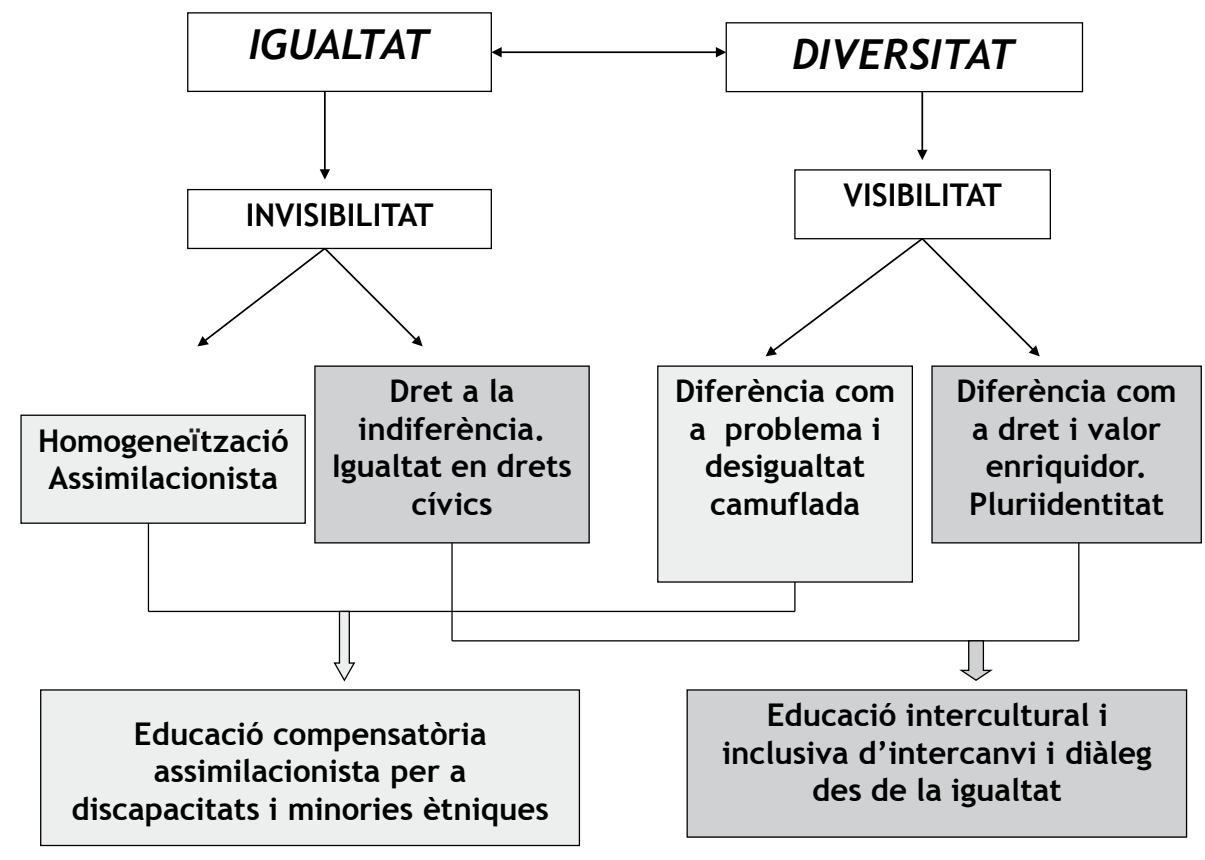

Figura 1. Igualtat i diversitat: entre allò visible i allò invisible 
Reconèixer i respectar la diversitat no significa tractar tothom per igual, sinó atendre les diferents necessitats de cadascun dels alumnes, ja que l'educació ha de compensar les desigualtats inicials. Com diu López Melero (1997:234):

Educar en la diversitat no es basa (com alguns pretenen) en l'adopció de mesures excepcionals per a les persones amb necessitats educatives específiques, sinó en l'adopció d'un model de currículum que facilite l'aprenentatge de tot l'alumnat en la seua diversitat.

En aquest procés democràtic, tothom hi ha de participar, no s'ha d'excloure a ningú, tothom ha de tenir veu i vot en la creació i recreació de la cultura en totes les seues manifestacions. No hi haurà interculturalitat ni inclusió fins que els grups i persones marginades d'aquesta participació puguen prendre part en la presa de decisions i en la transformació social i educativa que comporten enfocaments ideològics com l'intercultural i inclusiu (Oliver, 1998).

No es tracta de centrar-nos en polítiques de reconeixement, de celebració de la diferència i d'anàlisi psicològica de l'exclusió, sinó d'un desafiament a la tendència eurocèntrica que existeix en els conceptes d'història, marginalitat, modernitat $\mathrm{i}$ transformació (Giroux, 2001).

Per tot això, considere que l'educació intercultural i inclusiva comparteixen el compromís de transformació de l'educació cap a valors i actituds democràtics d'igualtat, respecte, autonomia i solidaritat.

La potència i radicalitat que tenen unides inclusió i interculturalitat té a veure amb la seua capacitat per propiciar la inserció en les activitats productives, per entendre el món i sentir-se com un actor social que intervé en el seu mitjà, un subjecte creador, lliure i autònom. Aquest potencial de la inclusió i la interculturalitat exigeix, al seu torn, que l'educació es plantege la importància de certs coneixements com a eines de pensament $i$ habilitats per aprendre $i$ comprendre dins i fora de l'escola en la societat actual, plural i que ha d'oferir la possibilitat de singularitzar-se en aquest procés de lluita per la inclusió (Gimeno Sacristán, 2000). 


\subsection{Models i polítiques educatives de gestió de la diversitat cultural}

Distingim en aquest apartat els diferents models de gestionar la diversitat cultural des de les polítiques i els programes educatius. En la taula següent, presentem un resum comparatiu dels trets diferenciadors dels diferents models, des de l'assimilacionisme fins a la interculturalitat.

Taula 1. Models teòrics de gestió de la diversitat cultural. Elaboració pròpia

\begin{tabular}{|c|c|c|c|c|}
\hline & Assimilacionista & Integracionista & Pluralista & Intercultural \\
\hline Cultura & $\begin{array}{l}\text { Etnocentrista } \\
\text { Estàtica } \\
\text { Homogènia } \\
\text { Grups tancats }\end{array}$ & $\begin{array}{l}\text { Etnocèntrica } \\
\text { Estàtica } \\
\text { Grups oberts } \\
\text { Visió folklòrica }\end{array}$ & $\begin{array}{l}\text { Relativista } \\
\text { Estàtica } \\
\text { Homogènia } \\
\text { Grups tancats }\end{array}$ & $\begin{array}{l}\text { Dinàmica } \\
\text { Oberta } \\
\text { Heterogènia } \\
\text { (pluriidentitat) }\end{array}$ \\
\hline Educació & $\begin{array}{l}\text { Transmissiva } \\
\text { Currículum: } \\
\text { monocultural } \\
\text { Compten els } \\
\text { resultats. }\end{array}$ & $\begin{array}{l}\text { Transmissiva } \\
\text { Currículum: un } \\
\text { model domi- } \\
\text { nant, més afegits } \\
\text { culturals secun- } \\
\text { daris. } \\
\text { Suports individ- } \\
\text { uals i adapta- } \\
\text { cions curriculars }\end{array}$ & $\begin{array}{l}\text { Transmissiva } \\
\text { Currículum: } \\
\text { incorpora tots els } \\
\text { grups culturals } \\
\text { Curricula dife- } \\
\text { renciats }\end{array}$ & $\begin{array}{l}\text { Dialògica } \\
\text { Currículum: } \\
\text { negociació i } \\
\text { consens per a un } \\
\text { model compartit. } \\
\text { Comú i plural }\end{array}$ \\
\hline Diversitat & $\begin{array}{l}\text { Disfunció social } \\
\text { Dèficit } \\
\text { Problema } \\
\text { Assimilable }\end{array}$ & $\begin{array}{l}\text { Ambigu: entre } \\
\text { el dèficit i la } \\
\text { igualtat d'opor- } \\
\text { tunitats. } \\
\text { Visió psicologi- } \\
\text { cista }\end{array}$ & $\begin{array}{l}\text { Emfatitza les } \\
\text { diferències } \\
\text { Reivindica la } \\
\text { identitat cultural. } \\
\text { Explicita la lluita } \\
\text { d'interessos } \\
\text { Impossibilitat } \\
\text { de comunicació } \\
\text { intergrupal }\end{array}$ & $\begin{array}{l}\text { Enriquidora } \\
\text { Positiva } \\
\text { Intrínseca a tot } \\
\text { subjecte i grup. } \\
\text { Explicita la lluita } \\
\text { d'interessos i de } \\
\text { poder. } \\
\text { Denúncia desi- } \\
\text { gualtats }\end{array}$ \\
\hline
\end{tabular}

\subsubsection{Model assimilacionista i política de compensació}

A principi dels anys seixanta va tenir una gran espenta en educació la perspectiva sasimilacionista, que es fomentava des de final del segle passat i durant la I Guerra Mundial. La ideologia assimilacionista pretén, bàsicament, l'absorció dels diferents grups ètnics i culturals en una societat que se suposa relativament homogènia. Per a aquesta assimilació l'únic criteri cultural que cal considerar és el de la cultura dominant. Part de la premissa etnocèntrica que la cultura receptora és superior a les altres i el seu afany consisteix a emprar tots els mecanismes possibles 
perquè les persones o els grups culturals minoritaris s'adapten totalment al model cultural dominant, ja que el contrari suposa una amenaça per a l'economia i la seguretat del país d'acollida. Des d'aquest enfocament la igualtat significa uniformitat (Hannoun, 1992).

La diversitat ètnica, racial, cultural..., la diversitat en general, es concep com un problema que amenaça la integritat i la cohesió social i que ha de ser reconduïda i compensada cap a plantejaments homogeneïtzadors que són, precisament, aquells que corresponen als grups majoritaris que controlen el poder polític i econòmic.

Aquest enfocament ha sigut criticat pel seu etnocentrisme, el seu concepte estàtic de la cultura i la societat, i per la seua desconsideració cap als factors estructurals que produeixen la desigualtat i la discriminació, i que converteixen la diferència cultural en alguna cosa «exòtica», deficitària i folklòrica (Torres, 2011).

Els programes elaborats segons aquest enfocament estan dirigits a les minories, els qui han de fer l'esforç de «superar-se» i adaptar-se als estàndars socials i culturals. Els programes bilingües són de transició o d'immersió en la llengua dominant (aprenentatge de segon idioma) i la introducció de la cultura minoritària en el programa s'utilitza per motivar l'interès de les minories per integrar-se en l'estructura, amb el mínim cost psicològic possible i sense amenaçar l'status quo.

Els programes d'enfocament assimilacionista, desenvolupats fonamentalment en els llocs on hi ha escolaritzades minories culturals, han sigut els pioners en el tractament de la diversitat cultural amb l'arribada massiva d'immigrants estrangers $\mathrm{i}$ han tractat d'integrar l'educació intercultural en la infraestructura i els plantejaments de l'educació compensatòria, merament assistencial per a les poblacions «marginades», i tractant, per exemple, les cultures gitana i àrab com a part d'un món marginal i deficitari (Sales i García, 1997).

\subsubsection{Model integracionista des de la política de compensació i relacions humanes}

Al llarg dels anys seixanta i setanta s'introdueixen nous elements a l'enfocament anterior. Va començar, així, a desenvolupar-se una actitud d'amalgamació més suau, que tractava de crear una cultura comuna que arreplegara les aportacions de tots els grups ètnics i culturals sense que cap s'imposara a la resta. És la idea de melting pot (cresol), segons la qual totes les diferències ètniques es fonen en una sola entitat nacional que és superior a totes elles per separat. La pretensió és mantenir la coexistència i l'equilibri entre les cultures minoritàries i oferir el millor de la cultura dominant per a tothom.

La proposta integracionista pretén ser un pas endavant respecte a la ideologia d'assimilació, ja que planteja la plena igualtat de drets per a tots els ciutadans i tracta de promoure la unitat mitjançant la diversitat, davant de polítiques segregacionistes 
criticades ja com a clarament discriminatòries $i$ vexatòries. Encara que es parteix de la mateixa idea de dèficit cultural, es comença a posar l'accent en la necessitat d'eradicar els estereotips i les actituds racistes i en la millora de la comunicació interpersonal a partir de la tolerància entre cultures. Per tant, la seua actitud és bastant ambigua, la qual cosa ha donat lloc a diferents interpretacions, des de les quals han convertit la integració en pura assimilació la qual cosa ha donat lloc a diferents interpretacions. Per alguns la integració s'ha convertit en pura assimilació. Altres interpretacions emfatitzen en la necessitat d'incorporar en el currículum la diversitat cultural i propiciar actituds d'interrelació, cooperació i empatia entre els alumnes de diferents cultures. Per a molts teòrics continua constituint una forma subtil de racisme i una creença en la superioritat de la cultura receptora (Banks, 2015). Del que es tracta, coste el que coste, és d'evitar el conflicte i el desequilibri social que puguen desestructurar l'ordre establit i mantenir les jerarquies de privilegis socials, i cedir només en aquells aspectes superficials que no destorben l'status quo.

El model d'integració és un dels més utilitzats en tots els països, i el que abasta el màxim ventall de propostes, en un contínuum que va des de la integració entesa com a assimilació fins a experiències molt properes a l'enfocament intercultural. Els programes revisats tenen com a meta essencial integrar tots els grups ètnics $i$ culturals i millorar així les relacions en contextos multiculturals. Mitjançant estratègies actives $i$ de comunicació es pretenen reduir els prejudicis i actituds racistes i discriminatòries, $\mathrm{i}$ crear un clima i un currículum que facilite l'enteniment en la diversitat, sense qüestionar tampoc l'estructura social subjacent, però fent-la més propícia al canvi.

Aquests programes es continuen compartint en alguns casos moltes de les premisses assimilacionistas compensadoras del tractament de la diversitat, però afavoreixen una major participació activa de les minories des d'enfocaments metodològics més constructivistes. No obstant això, la millora de les relacions interètniques proposada no planteja la diversitat cultural en sentit més ampli, sinó que continua restringint-se a les minories en contacte amb la cultura dominant. No es planteja l'educació intercultural com un model educatiu global per a tota l'escola, sinó en aquelles on es produeixen conflictes interètnics.

Tant en l'àmbit nacional com en l'internacional, solen incidir no només en la intervenció escolar, sinó també en el desenvolupament comunitari, i se n'amplia el context d'aplicació. No obstant això, continuen restringint-se les activitats a les minories que desitgen integrar-se en la seua comunitat. Per tant, mantenen encara un concepte de diversitat cultural i de l'enriquiment mutu molt limitat, a pesar que les estratègies metodològiques (cooperatives, autoavaluatives, interdisciplinaris), siguen compartides per enfocaments interculturals més globalitzadors (Torres, 1997). Es detecta també una falta de seguiment i avaluació d'alguns programes, que s'inicien i s'abandonen sense haver sigut valorats educativament. 


\subsubsection{Model pluralista i política d'estudi de grup}

Aquesta tendència, influïda per l'escola culturalista americana, té gran acceptació avui entre els teòrics i sorgeix com a rebuig a la jerarquització etnocèntrica de les cultures i de l'afirmació de la diferència cultural com a positiva. Cada grup cultural té dret a conservar i desenvolupar la seua cultura en el marc de la societat i a educar-se en els seus propis valors i coneixements culturals en igualtat de condicions.

Per als defensors del pluralisme cultural la identitat ètnica té gran importància en les societats modernitzades, ja que aquestes s'han anat construint pels grups ètnics competitius amb interessos polítics i econòmics contraposats. És més, consideren que el contacte entre cultures s'estableix sempre en condicions de lluita de poder i que cada grup cultural ha de defensar els seus propis interessos davant dels d'altres grups que tracten de sotmetre'ls, quan en realitat no existeix cap argument que justifique la superioritat dels uns sobre els altres.

Per això, en les escoles s'ha de donar cabuda a tots els grups culturals, i incorporar al currículum materials i continguts sobre cadascuna de les cultures representades, per tal de garantir que cada grup s'eduque dins del seu propi estil cultural, per la qual cosa s'arriba a advocar per una escola específica per a cada grup cultural (Banks, 2015).

Aquest enfocament, fugint de l'assimilació i l'homogeneïtzació, cau en la "guetorització» dels diferents grups culturals, i emfatitzant les diferències entre ells s'aïllen i s'intensifiquen les tensions i les hostilitats, en compte d'enriquir-se de la interrelació i buscar elements comuns i de connexió (Flecha i Gómez, 1995).

D'una banda, el pluralisme corre el perill de caure en un exagerat relativisme cultural que a la llarga continua discriminant els grups minoritaris, ja que no els facilita mitjans socials i intel·lectuals per participar en àmbits culturals més amplis. La defensa del dret a la diferència en una societat desigual pot servir de justificació d'un segregacionisme igual de racista que l'assimilacionisme homogeneïtzador que es tracta de combatre. D'altra banda, conceben la cultura com quelcom massa estàtic i essencialista; com un conjunt de costums, rituals, tradicions i valors que romanen invariables en el temps i que no contempla l'heterogeneïtat interna de cada grup (també hi ha lluites de poder dins d'un grup cultural) i nega la possibilitat de l'enriquiment produït per l'intercanvi i el mestissatge intercultural.

La política pluralista es basa en el paradigma educatiu del pluralisme cultural i la diferència cultural, segons els quals l'escola ha d'ajudar les noves generacions a desenvolupar compromisos amb el seu grup ètnic i cultural per lluitar per la seua legitimació i emancipació, i pel seu dret a triar el tipus d'ensenyament que volen, pel seu dret a triar el tipus d'ensenyament que volen i assumint el seu control. Es considera desitjable la coexistència de grups diferenciats que desenvolupen la seua identitat cultural plenament sense discriminar-ne cap i legitimant la diversitat cultural en una societat pluralista. 
En aquells països en els quals els grups culturals posseeixen el suficient poder polític i econòmic, el model educatiu seguit no és un altre que el segregacionista, la creació d'escoles específiques per als qui volen educar-se en la seua llengua d'origen, segons els seus valors religiosos o el seu estil cultural. D'una banda, això demostra que les cultures i les llengües «fortes» es mantenen, mentre que els grups que no hi posseeixen recursos ni poder les perden. No obstant això, aquesta política no és possible o és rebutjada des de actituds pluralistes menys extremistes i més conciliadores, que pretenen introduir en l'escola pública l'estudi dels grups ètnics que fins al moment han patit el menyspreu o l'oblit de la societat global i del seu sistema educatiu formal. Es parteix de la premissa que l'educació no és neutral, en oposició al pressupost que assumeixen els dos enfocaments anteriors (assimilacionista i integracionista). L'educació és un procés pel qual es perpetua l'alienació dels grups minoritaris socials i culturals, en pro dels grups majoritaris que imposen els seus punts de vista i els seus valors. Per tant, la política i el model pluralista tractaran de trencar aquest cercle reproductor amb la incorporació en l'escola dels coneixements i els valors dels grups marginats per tal de potenciar des de l'educació el canvi cap a una societat realment pluralista.

Podem relacionar aquesta política de conscienciació i lluita ètnica i cultural amb el model que Grant i Sleeter (1989) van anomenar d'estudis d'un grup cultural i que inclouria, encara que sovint no es fa, abastar no exclusivament grups ètnics sinó també estudis sobre les dones o sobre la classe treballadora. Consisteix a introduir en el currículum tradicional una sèrie de materials i continguts sobre un grup cultural específic, les seues gents, la seua història, la seua literatura, la seua forma de vida, i d'aquesta manera generar actituds d'empatia i acceptació cap a aquest grup concret per part del grup majoritari i augmentar la consciència i confiança en un/a mateix/a en els grups minoritaris, per trencar així l'hegemonia de la cultura dominant en la selecció del coneixement escolar considerat com a valuós.

En les versions més reivindicatives d'aquest model s'emfatitza, sobretot, la presa de consciència, tant per part del propi grup com dels altres, de la situació d'opressió i discriminació i de les seues nocives conseqüències per al grup cultural afectat, i proporcionar les bases per a una acció social mitjançant una cerca activa, per part de l'alumne, de la veritat i el coneixement, en el desenvolupament del que Freire anomena una consciència crítica.

En altres versions més «blanes», els continguts d'aquests estudis no passen de presentar elements culturals inconnexos fora del currículum tradicional. Es tracta de preparar celebracions lúdiques especials que reflectisquen les peculiaritats folklòriques o culinàries dels diferents grups culturals, i descontextualitzar així la cultura del seu entorn social i de la seua relació amb altres cultures, sense qüestionar l'estratificació social i l'opressió d'aquests grups i sense tenir en compte les múltiples formes de diversitat humana que existeixen (sexe, raça, religió, edat, classe social...,) i la seua interacció dinàmica, amb el que l'estudi és superficial i pot fins i tot enfortir els estereotips i prejudicis entre l'alumnat. En realitat aquesta aplicació desvirtua el vertader objectiu pluralista, i el reconverteix en un assimilacionisme encobert que neutralitzaria l'intent de reconstruir la política educativa, el currículum, el paper de l'escola i el lloc de les minories en la societat actual. 


\subsubsection{Model i política intercultural}

L'interculturalisme és la tendència més recent i tracta de compensar els extremismes als quals arriben l'assimilacionisme i el pluralisme cultural, partint d'un concepte de cultura més dinàmic i canviant que permet l'intercanvi i el diàleg entre els grups culturals i el seu mutu enriquiment. Es considera que els grups culturals evolucionen i es transformen gràcies al contacte mutu, gràcies a l'intercanvi entre ells. En aquest intercanvi han d'estar garantits els drets de tots els grups, i establir les condicions d'igualtat i justícia social necessàries perquè el diàleg $\mathrm{i}$ el mestissatge entre cultures siga realment enriquidor i no basat en relacions de poder desiguals (McCarthy, 1994). Per aquest motiu els objectius bàsics de l'enfocament intercultural són la lluita per la igualtat d'oportunitats i la cerca d'un diàleg cultural i social enriquidor (Taylor, 1993).

No considera cap cultura superior a una altra i amb dret a dominar-la, però tampoc comparteix amb els relativistes que totes les cultures valguen igual. Més aviat planteja una contínua reflexió crítica dels elements culturals, començant pels de la pròpia cultura, per anar bandejant tots aquells valors que entren en conflicte amb valors humans universals que han de ser compartits per totes les cultures, per la qual cosa s'hi fa necessari un continu diàleg sobre els valors interculturals (Sant Román, 1996).

L'interculturalisme tracta de posar el factor ètnic i cultural en la seua justa mesura $\mathrm{i}$ interconnectar-ho amb molts altres factors que condicionen les relacions entre els grups humans, com ara els factors econòmics, polítics, de gènere, de classe social, d'edat, etc. D'altra banda, com que es considera la diversitat cultural com a positiva, i no pas com un problema sinó com a expressió de la riquesa de l'espècie humana, no s'exacerben les diferències sinó que se cerquen els elements que poden unir els diferents grups i que permetran la comunicació i l'enteniment intercultural. Aquest plantejament de mestissatge $\mathrm{i}$ enriquiment parteix de supòsits d'igualtat i justícia social, sense els quals resulta impossible parlar de l'elaboració dialèctica d'una cultura compartida des del pluralisme democràtic.

Les polítiques segons el model intercultural pretenen reformar tot el procés educatiu per generar un ambient de diàleg i enriquiment intercultural des de tots els àmbits $\mathrm{i}$ implicar a tota la comunitat. S'abandona la concepció de la diversitat cultural com a deficitària i susceptible de compensació o adaptació i, en canvi, es tracta aquesta diversitat com a element dinamitzador de la innovació educativa que implica tots els agents i centres, i no solament aquells amb població marginal, minoritària $\mathrm{o}$ immigrant.

L'enfocament intercultural d'educació bilingüe se centra no tant en models d'immersió o transició, sinó també de manteniment de totes les llengües en contacte, la qual cosa suposa l'enriquiment lingüístic tant de la minoria com del grup majoritari.

Les estratègies educatives que s'empraven en altres enfocaments com a propícies per a les minories culturals o davant conflictes interètnics, en els programes d'enfocament 
intercultural es consideren generalitzables a totes les escoles que desitgen aprofitar la diversitat de la seua població i entorn, per enriquir el seu projecte educatiu amb una perspectiva crítica i participativa, és a dir, democràtica de la societat.

\subsubsection{Educació intercultural: un model per abordar la diversitat}

El model educatiu intercultural parteix de la premissa que la diversitat cultural pot ser positiva i no considerada com un problema si no s'entén com a expressió de la riquesa de l'espècie humana, no exacerbant les diferències sinó cercant els elements que poden unir els diferents grups i que permetran la comunicació i l'enteniment. Per aquest motiu davant el concepte multicultural, més descriptiu, diguem-ne «de foto fixa», advoquem pel concepte intercultural, com a proposta d'acció, on es fa evident la insuficiència del pluralisme entès com a suma o coexistència de cultures (Malgenisi i Jiménez, 2000).

Aquest plantejament de mestissatge $\mathrm{i}$ enriquiment parteix de supòsits d'igualtat $\mathrm{i}$ justícia social, sense els quals resulta impossible parlar de l'elaboració dialèctica d'una cultura compartida des del pluralisme democràtic. Si l'interculturalisme no és entès des d'unes premisses d'estructura social igualitària i per al desenvolupament de relacions socials i polítiques entre els diferents grups més justa i solidària, estarem confonent-nos de nou en el discurs fal·laç de l'assimilacionisme benigne del melting pot (Banks, 2015).

Des d'aquest enfocament, podem definir l'educació intercultural com:

un model educatiu que propicia l'enriquiment cultural dels ciutadans, partint del reconeixement i respecte a la diversitat, a través de l'intercanvi i el diàleg, en la participació activa i crítica per al desenvolupament d'una societat democràtica basada en la igualtat, la tolerància i la solidaritat (Sales i García, 1997:46).

D'aquesta definició es deriven els seus objectius fonamentals:

a) Oferir les condicions per a la igualtat d'oportunitats educatives i per a participar activament en la societat i en la transformació (construcció-reconstrucció) de la cultura, dins d'una societat democràtica en la qual es formen les noves generacions com a ciutadans crítics en la presa de decisions públiques per a desenvolupament de les estructures i les pràctiques socials i culturals.

Hem de reconèixer que no hi ha enriquiment $i$ veritable intercanvi cultural si no es donen condicions socials de simetria, d'igualtat i justícia: els temes de caràcter pretesament ètnic moltes vegades reflecteixen, sobretot, desigualtats socials més que diferències culturals (Kincheloe i Steinberg, 1999).

Així doncs, la diversitat és intrínseca a qualsevol grup humà, però hem de desenvolupar-la en societats que proclamen i defensen la igualtat de drets, 
la participació democràtica i el dinamisme de les cultures (Taylor, 2009). Encara que siguen imperfectes, ara per ara, els drets humans poden ser el punt de partida per entendre la interculturalitat i seguir una màxima: totes les persones mereixen respecte, però es poden i deuen qüestionar els valors i les pràctiques culturals que vagen contra la dignitat humana. És cert que no es pot partir d'un sol model cultural, però tampoc caure en el «tot val», és a dir, com si no es pogueren posar en dubte els trets culturals, i caure així en un relativisme cultural i moral que no afavoreix de cap manera l'intercanvi i la cerca de justícia i solidaritat (Flecha i Gómez, 1995).

b) Valorar la diversitat com a element dinamitzador i enriquidor en la interacció entre persones i grups humans. Per això, cal anar amb compte de no substituir l'antic racisme biològic per un nou racisme culturalista, que fa equivalent l'anacrònic concepte de raça al d'ètnia i aquest al de cultura, i es creen així determinismes i diferències suposadament insalvables entre els grups humans (Sant Román, 1996).

Això vol dir que no podem caure en falsos interculturalismes que enalteixen la diferència $\mathrm{i}$ en nom d'aquesta continuen segregant i discriminant determinats grups humans. Com molt bé va assenyalar Francesc Carbonell (1997), campanyes molt ben intencionades com la de «Som iguals, som diferents» van fer tant de ressò en la segona part de l'eslògan que es van oblidar de la primera, igual d'important o més. Si destaquem només la diferència, estem facilitant arguments als quals defensen actituds racistes de l'estil Li Pen: som diferents $i$ hem de preservar la diferència. El que justificaria segregar als immigrants perquè no es contaminaren.

c) Cerca d'uns valors mínims comuns, que donen sentit a la interculturalitat com a punts de referència axiològics per desenvolupar ideologies, polítiques i models educatius en un món plural, amenaçat per cert relativisme postmodern. Per a aquest propòsit es desenvoluparan estratègies comunicatives, socials $\mathrm{i}$ educatives basades en el diàleg, com a forma d'intercanvi de perspectives culturals i cerca de consensos i models alternatius (Díaz-Aguado, 2003).

d) Prendre consciència de les pràctiques socials i educatives individuals i collectives que propicien i resulten d'actituds estereotipades i prejudicis ètnics, culturals, sexuals o socials, i desenvolupar habilitats cognitives, afectives, conductuals, personals i socials per transformar aquestes pràctiques i les estructures que determinen i legitimen el racisme, que limita i exclou l'accés de determinats grups a l'ús normalitzat dels béns socioculturals (McCarthy, 1994).

e) Desenvolupament de competències multiculturals: conèixer, entendre i valorar diferents perspectives culturals per superar etnocentrismes paralizadors $i$ discriminadors. Implica tenir flexibilitat i capacitat d'adaptació al canvi: no solament quan es canvia de país, sinó per viure en societats que canvien la seua composició demogràfica i els seus valors de manera cada vegada més ràpida (Banks, 2015). 
f) Afavorir el desenvolupament d'una identitat cultural oberta i flexible, que incorpore els elements multiculturals de l'entorn, pels quals s'opte voluntàriament i sense amenaça cap a l'autoconcepte. Un dels qüestionaments de la modernitat passa per la crítica del concepte essencialista de cultura i l'estatisme i determinisme de la identitat cultural. Una de les conseqüències més clares de la postmodernitat és la concepció de la pluriidentitat de cada persona (Essomba, 2006).

En aquest sentit, el model intercultural comparteix les premisses del model inclusiu com a superador de les limitacions dels models compensadors i integradors, ja que la seua concepció de l'educació, la cultura i la diversitat són similars i no se centren exclusivament en aquells grups a priori estigmatitzats i convertits en problemàtics, sinó que advoquen per una educació per a tothom, en igualtat, des del principi democràtic d'universalitat de l'educació, considerant la diversitat, en totes les seues manifestacions, com a positiva i enriquidora, en un marc social i polític de lluita per la justícia (Sales, Traver i García, 2011).

\section{Activitats de reflexió-acció}

\section{a) Autoretrate cultural}

Et proposem que escrigues en un paper un ptit relat sobre com et veus a tu culturalment. Quins son els trets culturals que et defineixen com a persona a dia d'avui.

Aquest relat, el compartirem a classe i el contrastarem en diàleg amb la resta del grup, per veure de quina manera es conforma la diversitat cultural de les persones que cursen l'assignatura.

\section{b) Anàlisi d'activitats escolars interculturals}

Llegeix les activitats interculturals següents que es fan habitualment a les escoles d'educació primària i secundària, $i$ tracta de contestar les preguntes que trobaràs després dels tres requadres, per poder identificar el model educatiu de gestió de la diversitat cultural que fonamenta cadascuna de les propostes didàctiques.

\section{Activitat intercultural 1 : «Tots junts»}

Fase 1. Partim dels coneixements de l'alumnat: quines cultures coneixem? Quins són els seus trets més representatius?

Fase 2. Formen equips de 4-5 persones. Cada grup s'especialitza en una cultura i busca informació sobre: tradicions, gastronomia, música i danses, forma de vestir. 
Fase 3. Posem en comú el treball de cada grup i obrim el debat: quina cultura et sembla més interessant i per què? Quina et sembla més diferent i quina més semblant a la teua? A Espanya viuen amb nosaltres persones d'altres cultures: com creieu que podem fer que s'integren? Creieu que seria divertit tenir xiquets d'altres cultures a classe? Què faríem per ajudar-los?

Fase 4. Projecte final de grup-classe: col·laborem en la preparació d'una festa multicultural per celebrar la nostra societat com a cresol de cultures. Haurem de tenir en compte les cultures més representatives del nostre entorn: sudamericans, magrebins, africans, asiàtics, gitanos.

\section{Activitat intercultural 2: «Jo també sóc diferent»}

Fase 1. Partim dels coneixements previs de l'alumnat: què sabem de les altres cultures? En què es diferencien? Què té de positiu cadascuna?

Fase 2. Formen grups de treball de 5-6 persones perquè cada grup prepare un dossier (escrit, fotografies, audiovisuals) sobre les característiques de grup cultural estudiat: llengua, religió, estructura familiar i relacions home-dona, arts $i$ arquitectura.

Fase 3. Posada en comú del dossier de cada grup i debat obert: quins aspectes de cada cultura et semblen més interessants? Per què creus que és important conèixer la pròpia cultura? I conèixer-ne? Creus que hi ha alguna cultura millor que una altra? Penses que tothom té dret a gaudir de la seua pròpia cultura? Com es pot garantir el respecte a la diversitat cultural? Com ho faries tu a l'aula i al teu barri?

Fase 4. Projecte final col-lectiu: Organitzem unes «jornades multiculturals» en què convidem membres de diferents cultures (xinesa, gitana, senegalesa, algeriana, peruana i romanesa) per parlar de la pròpia cultura i ressaltar els aspectes que tothom ha de conèixer i valorar.

\section{Activitat intercultural 3: «Entre dues aigües»}

Fase 1. Partim dels coneixements previs de l'alumnat: què entenem per cultura? Quines influències culturals rebem cadascú de nosaltres? En quines coses som iguals i en quines, diferents? Coneixes algun grup o col·lectiu que estiga discriminat? Com i per què creus que passa?

Fase 2. Formen grups de 4-5 persones per fer un estudi de cas: una nena de pare gitano i mare paia que es troba atrapada entre paios i gitanos, perquè a l'escola es burlen d'ella per ser gitana, encara que intenta aplicar-se als estudis i al barri, amics i família li tiren per la cara que «fa coses de paia». Cada grup de treball identifica el conflicte, causes i conseqüencies, i tracta de donar-hi una solució argumentada: Què pot fer la xiqueta? Què es pot fer a l'escola i al barri? 
Fase 3. Posada en comú de les solucions al cas de cada grup de treball per obrir el debat: quina és la cultura de la xiqueta? Per què es burlen d'ella? Coneixeu la història del poble gitano a Espanya? Les cultures canvien? Com? Sabeu què és el racisme (clasisme, sexisme)? Què són els prejudicis i els estereotips? Com es generen? Busquem exemples al nostre entorn (amics, escola, barri, televisió, premsa). Com es poden combatre?

Fase 4. Projecte final del grup: plantegem un pla d'acció entre tots per millorar les condicions de vida de la gent del nostre barri i les relacions interculturals entre nosaltres a l'escola. Hem de tenir en compte els recursos del barri i l'escola, i les persones que poden col·laborar per portar-lo a la pràctica.

Anàlisi de les activitats escolars interculturals:

a) Quins conceptes de diversitat i cultura fomenta cada activitat?

b) Com s'entén la relació entre persones de diferents cultures?

c) Quins són els objectius de l'activitat?

\section{Lectures recomanades}

Abdallah-PRetceille, M. (2006): «Lo intercultural como paradigma para repensar la diversidad». Actas del Congreso INTER, Madrid, unED. Disponible en http:// www.uned.es/congreso-inter-educacion-intercultural/pretceille_espanol.pdf.

MALGENisi, G. y GimÉnez, C. (2000): Guía de conceptos sobre migraciones, racismo e interculturalidad, Madrid: Los Libros de la Catarata.

Sales, A. i R. García (1997): Programas de Educación Intercultural. Bilbao, Desclée De Brouwer.

\section{Recursos web recomanats}

AULA INTERCULTURAL: http://www.aulaintercultural.org/.

GRUPO INTER, UNED: http://www.uned.es/grupointer/.

\section{Referències}

Abdallah-Pretceille, M. (2001): La Educación Intercultural, Barcelona, Idea Books.

Abdallah-Pretceille, M. (2006): «Lo intercultural como paradigma para repensar la diversidad». Actas del Congreso INTER, Madrid, UNED. Disponible en http:// www.uned.es/congreso-inter-educacion-intercultural/pretceille_espanol.pdf.

Ayuste, A. i d'altres (1999): Planteamientos de la Pedagogía Crítica. Comunicar y transformar, Barcelona, Graó. 
BANKS, J. A. (2015): «Emigración global, diversidad y educación para la ciudadanía», dins Escarbajal, A. (Ed.): Comunidades Interculturales y Democráticas, Madrid, Narcea. 15-24.

Bauman, Z. (2008): Los retos de la educación en la modernidad líquida, Barcelona, Gedisa.

BECK, U. (2002): La sociedad del riesgo global, Madrid, Siglo XXI.

Besalú, X. (2002): Diversidad cultural y educación, Madrid, Síntesis.

Calvo Buezas, T. (1990): ¿España racista? Voces payas sobre los gitanos, Barcelona, Anthropos.

Calvo Buezas, T. (1995): Crece el Racismo, también la Solidaridad, Madrid, Tecnos-Junta de Extremadura.

CARBonell, F. (1996): Inmigración: diversidad cultural, desigualdad social y educación, Madrid, Ministerio de Educación y Ciencia.

Carbonell, F. (1997): «Entre la oveja Dolly y las reservas indias», Cuadernos de Pedagogía, 264, 24-19.

Chow, R. (1999): «Women in the Holocene: Ethnicity, Fantasy, and the Film The Joy Luck Club», dins Luke, C. (comp.) (1999): Feminismos y pedagogías en la vida cotidiana, Madrid, Morata.

Cushner, K. (1992): «Creating Cross-Cultural Understanding through Internationally Cooperative Story Writing», Social Education, 56, 43-46.

Delgado, M. (1998): Diversitat i integració, Barcelona, Empúries.

DíAz-Aguado, M. J. (2003): Educación Intercultural y aprendizaje cooperativo, Madrid, Pirámide.

Echeíta, G. i M. Ainscow (2011): «La educación inclusiva como derecho. Marco de referencia y pautas de acción para el desarrollo de una revolución pendiente», Tejeruelo, 12, 26-46.

Essomba, M. A. (2006): Liderar escuelas interculturales e inclusivas. Equipos directivos y profesorado ante la diversidad cultural y la inmigración, Barcelona, Graó.

Flecha, R. i J. Gómez (1995): Racismo: No, gracias. Ni moderno, ni postmoderno. Colección Debate, Barcelona, El Roure.

Geertz, C. (2000): La interpretación de las culturas, Barcelona, Gedisa.

Gimeno SACRistán, J. (2000): La educación obligatoria: su sentido educativo y social, Madrid, Morata.

Giroux, H. A. (2001): Cultura, política y práctica educativa, Barcelona, Graó.

Grant, C. A. i Ch. E. Sleeter (1989): «Race, Class, Gender, Exceptionality and Educational Reform», dins Banks, J. A. i Mcgee Banks, Ch. A. (eds.) (1989): Multicultural Education: Issues and Perspectives, Massachusetts, Allyn \& Bacon, 46-65.

Hannoun, H. (1992): Els ghettos de l'escola. Per una educació intercultural, Vic, Eumo.

Hawkins, D. F. (1991): «The discovery of Institutional Racism: An example of the interaction between law and social science», Research in Race and Ethnic Relations, 6, 167-182.

JiMÉNEZ, P. i M. VILA (1999): De educación especial a educación en la diversidad, Màlaga, Aljibe.

Kincheloe, J. L. i Sh. R. Steinberg (1999): Repensar el multiculturalismo, Barcelona, Octaedro. 
LAY, C. H. (1992): «If personal self-esteem predicts personal enhancements, will collective self-esteem predict collective enhancement?», Journal of Social Behavior and Personality, 7 (1), 189-200.

López Melero, M. (1997): «Escuela pública y atención a la diversidad. La educación intercultural: la diferencia como valor», dins vV. AA. Escuela pública y sociedad neoliberal, Màlaga, Aula libre, 115-150.

MALGenisi, G. y C. GimÉnEZ (2000): Guía de conceptos sobre migraciones, racismo e interculturalidad, Madrid, Los Libros de la Catarata.

McCarthy, C. (1994): Racismo y currículum, Madrid, Morata.

Oliver, M. (1998): «Una sociología de la discapacidad o una sociología discapacitada», dins Barton, L. (1998): Discapacidad y sociedad, Madrid, Morata, 34-58.

Pérez Gómez, A. I. (1993): «El aprendizaje escolar: de la didáctica operativa a la reconstrucción de la cultura en el aula», dins Gimeno SACRistán, J. i A, Pérez Gómez (1993): Comprender y transformar la enseñanza, Madrid, Morata, 63-77.

Ponterotto, J. G. y P. B. Pedersen (1993): Preventing Prejudice. A guide for counselors and educators, Califòrnia, SAGE.

SALES, A. (2002): «La diversitat als mitjans de comunicació des d'un enfocament intercultural», Guix: El contracte didàctic, 282, febrer, 66-73.

Sales, A. i R. García (1997): Programas de Educación Intercultural, Bilbao, Desclée de Brouwer.

Sales, A. J. Traver i R. García (2011): «Action research as a school-based strategy in intercultural professional development for teachers», Teaching and Teacher Education, 27, 911-919.

SAN Román, T. (1996): Los muros de la separación. Ensayo sobre alterofobia y filantropía, Barcelona, Tecnos-UAB.

Schutz, A. (1987): Le chercheur et le quotidien, phénoménologie des sciences sociales, París, Méridiens Klinksieck.

TAYLOR, Ch. (2009): El multiculturalismo y la política de reconocimiento, Mèxic, Fondo de Cultura Económica.

Torres GonzÁlez, J. A. (1999): Educación y diversidad. Bases didácticas y organizativas, Màlaga, Aljibe.

Torres, X. (2011): La justicia curricular. El caballo de Troya de la cultura escolar, Madrid, Morata.

Touraine, A. (1997): ¿Podremos vivir juntos? Iguales y diferentes, Madrid, PPC. 


\section{Contextos socioeducatius interculturals: com ens organitzem?}

\section{Introducció}

El segon bloc temàtic, el tema 2, se centra en l'anàlisi de contextos socioeducatius. Cal entendre la gestió de la diversitat de manera contextualitzada, en interacció (per tant, des d'un enfocament intercultural) i és necessari conèixer eines i models d'anàlisi dels contextos socioeducatius. Exposem en aquest tema tres propostes:

a) Des de la semiótica aplicada a la pedagogia, que analitza els contextos educatius com a espais de representació i les pedagogies invisibles que implica. Es proposa una anàlisi dels espais educatius i les possibles estratègies de resistència i canvi, i fa visibles els elements que l'acte educatiu ha posat en joc al crear un imaginari, una posició i una actitud dels actors docent $\mathrm{i}$ discent.

b) Des de dinàmiques de diagnòstic social participatiu, pròpies de la investigació-acció participativa, que té com a objectius que l'anàlisi i el canvi social es desenvolupen en el context per la pròpia comunitat en col·laboració amb els professionals externs, com en aquest cas puguen ser els i les professionals de l'educació i la psicopedagogia.

c) Des d'instruments d'autoavaluació escolar amb indicadors d'inclusió i interculturalitat com la Guia CEIN (Guia de Construcció de l'Escola Intercultural Inclusiva), que el grup d'investigació MEICRI ha adaptat a partir de l'Index for Inclusion de Booth i Ainscow. Les preguntes de reflexió estan orientades per les dimensions $i$ els indicadors que la literatura internacional ha assenyalat com a fonamentals per caracteritzar les escoles interculturals inclusives: valors compartits, altes expectatives, cultura collaborativa, xarxes de suport, participació comunitària, lideratge compartit, aprenentatge cooperatiu i situat, desenvolupament professional i competències de comunicació intercultural.

Des d'aquestes tres perspectives (de les pedagogies invisibles a la representació de l'acte educatiu; dels indicadors de qualitat d'una educació per tothom; i del canvi social des de l'emancipació de la comunitat) abordem els contextos a gestionar per a la transformació social, entenent-la des d'una ciutadania crítica que participa activament i s'empodera per millorar el seu entorn. Es relaciona aquesta ciutadania crítica amb l'educació intercultural, els seus objectius i les funcions i els perfils dels professionals de la psicopedagogía per formar part d'aquest moviment social amb estratègies d'intervenció educativa. 


\subsection{Com aprenem del context? Elements clau per comprendre i millorar el nostre entorn}

\subsubsection{Aprendre en situació}

Tant la construcció de la nostra identitat cultural com tots els nostres aprenentatges, els fem en societat, en el nostre context de convivència i a partir de totes les nostres experièncias amb l'entorn, les persones amb qui interactuem, els objectes $i$ productes culturals i naturals que utilitzem, i els espais i temps que habitem.

Aquesta concepció constructivista de l'aprenentatge és coherent i ve arrelada als conceptes dinàmics de cultura i d'interculturalitat. La interculturalitat parteix del concepte de comunitat que genera diàleg per a la construcció d'un coneixement compartit al qual anomenem cultura. Per tant, el coneixement sobre la realitat no existeix sinó des de la interpretació que les persones i els grups en fan. És la interacció amb el medi físic i social la que enceta el procés de construcció del coneixement i d'aprenentatge.

En aquest sentit la interacció entre els subjectes en els diferents contextos en què viuen produeix un progrés intel·lectual gràcies al conflicte sociocognitiu que mobilitza i força les reestructuracions intel-lectuals quan els subjectes en una activitat social confronten els seus punts de vista, creences i informacions, $i$ tracten de resoldre el seu conflicte cercant noves perspectives, en una tasca que pressuposa intersubjectivitat. La noció d'aprenentatge situat indica precisament el caràcter contextualitzat de l'aprenentatge, que no es redueix a les nocions convencionals d'aprenentatge in situ o aprendre fent, sinó a la participació de l'aprenent en una comunitat de pràctica, o siga, en un context cultural social de relacions d'on obté els sabers necessaris per transformar-la i transformar-se.

De la naturalesa d'aquestes situacions d'aprenentatge (activitats socials, segons Vygotsky, 1973) dependrà que l'alumne interioritze els nous coneixements (activitats individuals). Per a aconseguir-ho, els contextos socioeducatius i els mediadors o persones facilitadores deuen planificar els intervencions educatives de manera que donen sentit a l'experiència i provoquen l'aprenentatge.

La convivència intercultural provoca situacions autèntiques per generar aprenentatge situat, entès com «la forma de crear significat des de les activitats quotidianes de la vida diària» (Sagástegui, 2004:31). Curiosament, podríem dir el mateix de la cultura, ja que al·ludeix al complex entramat de relacions existents entre el coneixement i l'entorn on aquest es produeix. De tal manera que l'aprenentatge es pot considerar com una pràctica social (Lave i Wenger, 1999) i en aquesta pràctica la cognició humana és distribuïda, i es desplega entre la ment, el cos, l'activitat i els entorns organitzats culturalment (Lave, 1991:17).

Les activitats que realitzem quotidianament en la nostra vida posen en joc les percepcions, significats i intencions, que van situant-se en context i que són mediatitzades culturalment per llenguatges, símbols i representacions de la realitat. 
En qualsevol lloc o moment els aprenentatges s'activen i es generen situacions inesperades, perquè els aprenentatges no es poden dissenyar, com bé ens assenyala Wenger (2001), només podem generar situacions socials (situacions autèntiques) que puguen fomentar-lo, però sempre quedarà una incertesa intrínseca entre la manera en què s'ha dissenyat la situació i la resposta que s'hi donarà. Per tant, l'activitat té una forma molt indeterminada, però de gran poder creador.

Així, la pròpia activitat educativa, convivint, dialogant en les sessions de treball, recorrent i reconeixent els territoris locals, posa en moviment els sabers i els va construint en funció de la situació concreta (enacció) i del significat que cadascú atribueix a l'experiència.

L'educació intercultural, com a experiència d'aprenentatge situat, suposa un procés d'experimentar «transculturacions», una articulació entre mirades culturals que tracta de desxifrar com allò incert es torna ocasió d'aprenentatges (Sagástegui, 2004).

En el nostre món contemporani, caracteritzat per l'excés d'informació, de signes, d'hibridacions culturals i d' "apropaments» entre tots els habitants del planeta, ens plantegem l'educació intercultural des d'una perspectiva pedagògica no prescriptiva, que busca estratègies educatives des de la construcció dels sabers compartits, i que entén l'educació com una continua reinvenció de la realitat i la cultura (Sagástegui, 2004).

Aprendre implica participar de manera activa en les pràctiques de les comunitats socials, així com construir identitats en relació amb aquestes comunitats, ja que participar en una pràctica no només dóna forma al que fem, sinó també conforma qui som i com interpretem el que fem. El coneixement és una qüestió de competència en relació amb certes empreses valorades socialment; $i$ conèixer és qüestió de participar en la consecució d'aquestes empreses comprometent-se d'una manera activa en el món. El significat és en última instància el que ha de produir l'aprenentatge, però el significat no existeix ni en nosaltres ni en el món, sinó en la relació dinàmica de viure en el món.

Concebem les identitats com a relacions vivencials a llarg termini entre les persones, els seus llocs i la seua participació en comunitats de pràctica. Així, identitat, coneixement i sentit de pertenença interactuen uns amb altres. Per tant, és fonamental el concepte de comunitat de pràctica, que implica participació en un sistema d'activitat on els participants comparteixen la comprensió del que estan fent i del que significa açò en les seues vides i per a les seues comunitats. Els membres tenen diferents interessos, fan diferents contribucions a l'activitat, i mantenen una gran varietat de punts de vistes. A més, no implica necessàriament copresència, un grup identificable ben definit, o límits socialment visibles... Una comunitat de pràctica és un joc de relacions entre persones, activitat, món, en un temps i en relació amb altres comunitats de pràctica tangencials i superposades. Una comunitat de pràctica és una condició intrínseca per a l'existència del coneixement, ja que proveeix el suport interpretatiu necessari per donar sentit a la seua herència (Lave i Wenger, 1999). 
I així, des de la concepció situada de l'aprenentatge i la necessitat d'aprendre dintre de comunitats de pràctica que donen sentits als nostres aprenentatges com a pràctiques socials, abordem l'anàlisi dels contextos socioeducatius per gestionar la diversitat cultural.

\subsubsection{Analitzar el context socioeducatiu i transformar-lo}

a) Anàlisi semiòtic. Pedagogies invisibles dels espais

Si reconeixem el caràcter representacional de l'acte pedagògic, podem emprar una anàlisi semiòtica de l'acte pedagògic per prendre consciència de quins són els elements i recursos que es posen en joc en els procesos d'ensenyament-aprenentatge.

La semiótica entesa com a ciència que estudia la forma en què entenem els missatges que ens arriben de la realitat $i$ en concret la semiòtica pragmàtica, que se centra a estudiar els signes en relació a l'usuari i al context, ens pot ajudar a fer visible allò que queda invisible en els contextos educatius (pedagogies invisibles), per fer evidents les representacions que hem automatitzat i invisibilitzat (per la rutina) $i$ així poder-les transformar.

Aquesta és la proposta que prenem de Maria Acaso (2012) per repensar l'espai de l'aula com un teatre, una escenografía que té un guió preestablert i que posa en relació diferents personatges.

D'aquesta manera, podem entendre que el currículum també és un sistema de representació que construeix una mirada determinada de la realitat, no és la realitat. Com a professionals de l'educació, triem el punt de vista que adoptem quan ens situem en un espai i un acte pedagògic. Hem de ser conscients de la direccionalitat que donem a la nostra docència.

En l'acte pedagògic generem una narració, un relat sobre la realitat i l'escenifiquem per a els altres. Per tant, generem contextos d'aprenentatge, comunitats de pràctica $\mathrm{i}$ activitats que posen en acció i, per tant, construeixen el nostre coneixement sobre el món. Per tant, saber analitzar contextos és una activitat intel lectual pràctica, creativa, tal com deia Joan Foncuberta (2010:16): «L'acte de creació més genuí i coherent no consisteix a produir noves imatges, sinó a assignar contingut a les existents». Estem d'acord amb Acaso (2012) que mirar de determinada manera pot ser un acte de creació, i així, els processos d'anàlisi són actes de creació en pedagogia.

Així doncs, pensat l'acte pedagògic com una representació mediada (qui és el mediador, com ho fa, per què i per a què), podem analitzar de quines maneres aquesta representació està construïda, igual que al teatre ens situem com a espectadors en una representació que simula ser real.

Descobrir quines són les pedagogies invisibles, com a microrelats múltiples que van conformant una estructura o macrorelat que ès l'acte pedagògic. Històricament 
la pedagogia crítica ha fet aquesta anàlisi crítica fent visible el currículum ocult, allò que s'aprèn però no està oficialment planificat, allò implícit a l'educació. Malgrat haver significat un gran avanç, sembla que aquesta reflexió crítica no vaja més enllà de deconstruir, desarmar una manera de representar la realitat a l'acte pedagògic, però no ha generat un discurs de transformació, d'optimisme, de regeneració. Com diu Elisabeth Ellsworth (2005), ens deixa sumides al fracàs de la comprovació dels nostres propis errors. En lloc d'empoderar-nos i encendre les ganes per abordar la transformació i canviar el món, la pedagogia critica ens fa sentir derrotats.

Per tant, busquem fer anàlisi crítica de contextos per fer transformacions, per generar escenaris, pràctiques, activitat social que afavorisquen la interculturalitat, que reconeguen la diversitat i generen nous relats personals i col·lectius de creixement i millora.

En aquest sentit, hem de tenir en compte que fer visibles les pedagogies invisibles implica considerar cinc elements bàsics que cal tenir en compte a l'hora d'analitzar un context educatiu (Acaso, 2012):

a) Violència simbólica: l'acte pedagògic es un acte violent, on uns grups dominen uns altres a través dels continguts, les categoritzacions, les normes invisibles per les quals mantenir la seua situació de poder sense fer explícit el procés de dominació. La invisibilitat és una característica fonamental d'aquest tipus de violència. (Exemple: portar uniforme, estar hores asseguts, callar quan volem parlar). Ens podem preguntar: quin tipus de violència pot implicar la manera en què està organitzat aquest context educatiu?

b) Currículum opac: és aquell que s'amaga en capes de funcionalitat i practicitat, més enllà de la violència simbòlica. Exemple: ús de l'entarimat: currículum ocult (control visual com a panòptic per part del professor), currículum opac (amaga aquesta idea violenta en una de funcional: tots els estudiants veuen millor el professor. Canvia la idea «estic ací per poder veure't millor» per «estic ací perquè em pugues veure millor». Perversa invisibilitat del propi currículum ocult. Ens preguntem quin és el currículum opac que està tapant el curricululm ocult de la meua classe?

c) L'aprenentatge de l'absència: Elliot Eisner encunya el terme currículum nul o currículum absent. Es tracta d'allò que aprenem del que no ens ensenyen. Aquelles coses que els docents donen per òbvies, que l'estudiant acaba oblidant $\mathrm{i}$ les institucions releguen de la seua memòria històrica. El que no s'inclou (conscientment o inconscientment), les veus absents, els fets absents. Cal preguntar-se per les absències i qüestionar quina importància té el que no s'està ensenyant, aquells llocs que ni tan sols han sigut concebuts com a pedagògics. Ens podem preguntar quines absències o veus silenciades hi ha en el nostre acte pedagògic?

d) La direccionalitat: ve del món del màrqueting, però en educació té a veure amb com dissenyem el currículum, com el guió d'una pel·lícula segons qui 
van a veure-la, el nostre alumne ideal. És un conjunt de coses que engeguem per viure amb els nostres estudiants, el que volem explicar i com, embolicar-los en el rizoma $i$ transformar-nos junts. Ens preguntem quines accions s'han dissenyat pensant en tots els estudiants, no només en l'ideal que s'assembla al professor o professora.

e) Performativitat: introduït per Austin en filosofia del llenguatge i que ha treballat Judith Butler des del feminisme (Butler, 2007). Assenyala que el llenguatge performa la realitat, fa que els nostres cossos reaccionen i passen coses, no només és una manera de comunicació (veure's avaluat, llevar taules $i$ fer un cercle per dialogar, etc.). Ens preguntem com afecta això al comportament dels estudiants? La seua participació, implicació, la seua pròpia transformació i empoderament.

Des d'aquesta anàlisi semiòtica de les pedagogies invisibles podem començar a plantejar la transformació dels espais d'aprenentatge, tenint en compte que l'acte no l'acabem ni tanquem nosaltres, tampoc l'estudiant, sinó l'inconscient. El tercer component en el diàleg, que crea un triàleg. Per això el que aprèn l'estudiant no és el que va succeir a l'aula. Així doncs, podem dir que ensenyar és impossible. Ningú tanca l'acte pedagògic, que no té fi, és un continu de contextos i espais d'aprenentatge, un rizoma en el qual es van embolicant totes les persones participants (Acaso, 2012).

b) Investigació-acció participativa i mirada etnogràfica

La investigació-acció participativa (IAP) és un procés sistemàtic que duu a terme una determinada comunitat per arribar a un coneixement més profund dels seus problemes i tractar de solucionar-los, intentant implicar-ne tots agents en el procés (Bartolomé i Acosta, 1992). El seu objectiu principal és la presa de consciència del grup i per això comporta un procés d'aprenentatge i d'immersió en la seua pròpia realitat. Barham i Fals Borda (1992) assenyalen que la IAP té com a focus central el canvi social que faça efectives la igualtat i la democràcia. Per tant, es tracta d'un procés metodològic i de recerca que té com a eix central la reflexió i l'acció, mitjançant processos de participació democràtica, que generen coneixement mitjançant una construcció conjunta.

El procés està integrat per quatre fases o moments interrelacionats: planificació, acció, observació i reflexió. Cadascun dels moments implica una mirada retrospectiva, i una intenció prospectiva que formen conjuntament una espiral autoreflexiva de coneixement $\mathrm{i}$ acció.

L'actuació de tota la comunitat és fonamental en el procés i es converteix en el principal agent d'anàlisi, transformació i millora social. La finalitat és que la pròpia comunitat puga conèixer, analitzar, potenciar i proposar nous plans d'acció cap al canvi. D'aquesta forma garantim la «triangulació» de fonts, és a dir, la verificació de resultats a partir de diverses fonts d'informació, eines d'indagació i participants. 
El model es representa en una espiral de cicles, cadascun dels quals comprèn quatre moments (Latorre, 2003):

1. Pla d'acció: prospectiva de l'acció. El desenvolupament d'un pla d'acció críticament informat per millorar allò que està ocorrent. Aquesta fase estarà estructurada per les fases que Alberich et al. (2009) ens proposen per a la IAP.

a) Fase d'autodiagnòstic: s'hi duu a terme la primera recollida d'informació, es realitza la cerca d'elements analitzadors i s'inicia un primer diagnòstic de la situació inicial. Es partirà d'una aproximació etnogràfica que ens permeta indagar en profunditat en l'ethos de la comunitat, col·lectiu o institució: gestió, presa de decisions, relacions interpersonals, biografies i trajectòries vitals i professionals...). La recollida de dades des de diferents punts de vista, estratègies i informants ens permet, al seu torn, triangular la informació per tenir una visió multidimensional i complexa que permeta la formulació de l'acció estratègica que cal posar en pràctica (Woods, 1987). En aquesta fase utilitzem les tècniques de diagnòstic social participatiu i una guia d'autoavaluació com a eines que ajuda a orientar l'exploració i el diagnòstic comunitari de la realitat educativa. Ambdues seran detallades en els apartats posteriors.

b) Fase de treball de camp i primeres propostes: diagnòstic de la realitat. En aquesta fase comença el diagnòstic social participatiu a través de tallers amb diferents dinàmiques de participació comunitària.

c) Fase de conclusions i propostes d'acció. En aquest moment es retorna la informació arreplegada de tota la fase anterior i es realitza la lectura crítica d'aquesta. En aquesta fase també es poden utilitzar tècniques de diagnòstic social participatiu que faciliten els processos de concientització. Així s'arribarà a l'elaboració de les conclusions i les propostes d'acció.

d) Fase d'informe final i formulació de l'acció estratègica. Es realitza la posada en comú de la formulació de la proposta de canvi o millora: acció estratègica.

2. Acció: retrospectiva guiada per la planificació. Acords per posar el pla en pràctica. Una vegada planificades i dissenyades les propostes d'acció, s'engeguen les hipòtesis d'acció o accions estratègiques. Durant aquest procés es fa un seguiment mitjançant l'observació sistemàtica i la recollida de dades, és a dir, un acompanyament de la posada en pràctica de l'acció que permeta el control d'aquesta i la comprensió dels canvis. L'acompanyament inclou processos d'assessorament per part de l'equip psicopedagògic (indagació col·laborativa) en cas de requerir-ho com a part de l'acció estratègica.

3. Observació: prospectiva per a la reflexió. S'observen els efectes de l'acció en el context en el qual tenen lloc. En aquest moment del cicle la guia d'autoavaluació torna a servir d'instrument útil per orientar l'observació i la 
valoració dels canvis produïts per l'acció. Aquesta guia estableix els criteris o estàndards per identificar i valorar les millores que han tingut lloc en la pràctica educativa. S'analitzen els aspectes observats a la llum dels criteris establits per ser avluats.

4. Reflexió: retrospectiva sobre l'observació. Es reflexiona sobre aquests efectes com a base per a una nova planificació, una acció críticament informada posterior, a través de cicles successius. És el moment de centrar-se en què fer amb les dades, de decidir com interpretar la informació. La reflexió o anàlisi de dades, l'entenem com el conjunt de tasques amb la finalitat d'extraure significats rellevants, evidències o proves en relació amb els efectes o les conseqüències del pla d'acció.

Les tasques que cal realitzar són:

a) Recopilació: transcriure els documents, lectura selectiva i subratllar, anotar idees.

b) Reducció de la informació: codificar i categoritzar (categories inductives, deductives i mixtes).

c) Disposició i representació de la informació: gràfiques (diagrames, matrius, perfils).

d) Validació de la informació: com a estratègia de qualitat la credibilitat s'aconsegueix a través d'estades perllongades en el camp, observació persistent i triangulació.

e) Interpretació de la informació: teorització i replantejament de l'acció. Significa assumir els resultats, conceptualitzar-los i portar-los a la pràctica. És el moment de respondre a les preguntes que la recerca formulava durant el procés. D'ací sorgeixen noves hipòtesis d'acció a partir de l'evidència oposada i així continua el procés d'indagació en el centre, i s'inicia un nou cicle d'investigació-acció.

Aquesta última fase porta amb si la difusió de resultats perquè, de manera participativa, s'engeguen noves hipòtesis i propostes de millora, nous plans d'acció, a partir dels que s'han realitzat anteriorment $\mathrm{i}$ els seus resultats, analitzats per tots els col·lectius de la comunitat. És important fer la tornada dels resultats, compartir-ne la interpretació amb els participants, que són els que estan gestionant el procés de canvi i n'han de ser protagonistes, i sentir-se empoderats per liderar-ho.

En aquest procés de reflexió i acció participatives, la mirada etnogràfica és necessària i molt rellevant, ja que l'etnografia com a metodologia per comprendre i aprehender la realitat sociocultural d'un grup humà té una perspectiva holística. Tracta d'entendre les experiències i els punts de vista dels membres d'una comunitat en el seu propi context, tot relacionant múltiples dimensions i considerant diferents veus i posicions en l'entramat social que s'estudia. La comprensió de la realitat exigeix la contextualització, és a dir, dimensionar-ho respecte al conjunt de factors o elements que hi incideixen o intervenen i que finalment 
es revelen en extensió quasi indefinida, com un conjunt estructurat, com un tot (Fernández Sierra, 2013).

Ens permet fer un relat dens del que allí passa i per què es produeix, entendre les possibles contradiccions i els discursos contraposats. L'etnografia, com a part de l'antropologia social, ens mostra la realitat en tota la seua complexitat, facilita el actitud d'estranyament (és un terme de metodologia etnogràfica. Actitud d'estranyar-se davant una cultura o context per generar la necessària distància investigadora) i, per tant, la possibilitat de fer visibles mecanismes, estratègies, rutines que, als mateixos participants, poden ja passar-los desapercebudes perquè en formen part de manera «natural».

La intenció de l'etnografia d'aprehensió de totalitat implica que les tècniques per arreplegar o més aviat produir informació, les fonamentals -observació participant i entrevista- han de ser flexibles per acomodar-se a l'heterogènia naturalesa de les situacions que cal estudiar i relatar. Ambdues tècniques comparteixen el supòsit de fer accessible la pràctica totalitat dels fets, i generalment es tenen com a complementàries, per poder així captar els productes i els models, els comportaments i els pensaments, les accions i les normes, els fets i les paraules, la realitat i el desig. Ambdues tècniques produeixen dos tipus bàsics d'informació en el treball de camp, que es corresponen, respectivament, al que es denomina 1) categoria ètica $i$ categoria èmica: ètica, discurs que basa la seua racionalitat fora d'un sistema, i èmica, discurs que basa la seua racionalitat dins d'un sistema particular:

a) L'observació participant proporcionen descripcions, és a dir, discurs propi, de l'investigador.

b) L'entrevista, teixida sobre el diàleg, proporciona discurs aliè, dels subjectes d'estudi.

A més existeixen moltes altres tècniques: censos, mapes, qüestionaris, taules, llistats, gràfics, dibuixos, fotografies, films, enregistraments sonors, documents, etc. En tot cas, tota aquesta varietat de materials arreplegats no són una mera recopilació, sinó que són informació elaborada per l'investigador, per tant, hi ha una implicació directa i personal en els elements i peces amb els quals es construeix el relat (Velasco i Díaz de Rada, 1997).

\section{Diagnòstic social participatiu: l'avaluació participativa}

Dins de l'espiral de investigació-acció participativa una de les eines que cal utilitzar són les tècniques de diagnòstic social participatiu (DSP). El seu objectiu principal és facilitar espais de reflexió col·lectiva que conduïsquen a compartir objectius i iniciar processos creixents de participació-acció (Bermejo, Lobillo i Molina, 2002). Mitjançant les tècniques de diagnòstic participatiu es realitzen accions orientades a l'enfortiment de l'organització a través de la participació dels seus membres, l'anàlisi i la reflexió dels problemes i la cerca de possibles solucions, formulant estratègies o planificant accions (Moliner, 2012). 
Martínez (1995) exposa que el DSP està format per les característiques següents: els membres de la comunitat són els que identifiquen les seues necessitats, analitzen les causes $\mathrm{i}$ els efectes dels seus problemes i determinen les fortaleses i febleses per a la cerca de solucions. Aquesta dinàmica permet que els qui hi participen puguen provar la seua pròpia capacitat de produir i executar les seues idees, criteris o accions, i que aquesta capacitat puga crear un procés col-laboratiu i organitzatiu permanent en el temps. Perquè això siga possible han de promoure el diàleg i la discussió des de la comunicació horitzontal i l'estímul del potencial crític i creatiu dels participants.

El DSP s'estructura en quatre fases bàsiques, al llarg de les quals es desenvolupen diferents dinàmiques o tècniques basades en el diàleg, la cooperació i la representació visual de les aportacions dels diferents participants.

Fase I. Història del grup. Es tracta de conèixer la trajectòria conjunta del grup, qui són, d'on vénen i com es veuen i els veuen. La imatge que es crea de la comunitat no és estàtica sinó que es modifica en funció de les necessitats dels participants al llarg de tot el procés. Una dinàmica utilitzada en aquesta fase és la línia de vida o línia del temps (Alberich i altres, 2009). Amb ella s'arrepleguen els esdeveniments claus de la història de la comunitat $i$ el seu entorn, els quals ens ajudaran a identificar tendències passades, esdeveniments importants, problemes o triomfs, sobre les pràctiques en la vida d'aquesta comunitat.

Fase II. Cerca de necessitats. Es caracteritza per l'anàlisi crítica de la realitat. Se'n pren consciència d'ella amb la intenció d'engegar accions que la milloren. Una tècnica per a aquesta fase és el mapeig social, com a acostament de la comunitat al seu espai geogràfic, socioeconòmic i històricocultural. La construcció d'aquest coneixement es realitza mitjançant l'elaboració collectiva de mapes que posen en evidència diferents tipus de sabers que es barregen per poder arribar a una imatge col·lectiva del territori. Es poden construir mapes del passat, del present $\mathrm{i}$ del futur o mapes «temàtics» (mapa de xarxes socials, mapa de conflictes, mapes econòmics...), ja que els mapes són productes simbòlics i culturals, les cartografies han d'estar d'acord amb el context sociocultural en el qual s'emprèn (Habegger i Mancila, 2006).

Fase III. Priorització i presa de decisions. L'objectiu principal se centra en la reflexió de les necessitats que han sorgit en la fase anterior. Serà el moment de decidir en grup quins són les nostres prioritats i quina elecció realitzar per poder configurar un pla d'acció conjunt. Mitjançant les dinàmiques corresponents, cada persona de forma individual i el grup de forma general, argumentarà les seues valoracions quant a les necessitats que han sorgit. En acabar aquesta fase hem de tenir una llista categoritzada, amb totes les seues prioritzacions exposades en relació a totes les propostes sorgides. Es durà a terme amb la dinàmica de la bola de neu (García i altres, 2000; Aguirre, 2012). Aquesta és una tècnica basada en el consens argumentatiu. S'hi combina la participació amb l'aportació individual i el treball en grup a l'hora de prioritzar. 
Fase IV. Planificació de l'acció. Es tracta d'engegar accions que ens permeten arribar a les millores que es desitgen. Per a la consecució de les prioritats marcades es configuren grups de treball heterogenis, que treballen de forma coordinada i cooperativa en posada en marxa de l'acció.

En cadascuna de les fases les dinàmiques es completen amb una devolució de la informació a través de la tècnica d'espill (Deltoro, 2006; Aguirre, 2012), basada en la devolució de la imatge creada a partir de les dades obtingudes en la fase anterior. Permet, des d'una orientació comunicativa, realitzar una interpretació dialògica dels resultats de la recerca mitjançant la negociació i la discussió horitzontal de les interpretacions de totes les persones participants. Amb aquesta els participants es posicionen com a amos de la seua pròpia informació, i poden realitzar una reflexió crítica sobre la imatge construïda amb la informació que s'ha arreplegat amb anterioritat (Aguirre, Escobedo i Sales, 2014).

c) Guía CEIN. Una eina d'autoavaluació

La Guia CEIN (Guia per a la construcció de l'escola intercultural inclusiva) (Sales, Traver i Moliner, 2010) és un recurs per a la reflexió i l'autoavaluació, des d'un enfocament intercultural inclusiu, utilitzat en diversos estudis del grup de recerca MEICRI, de la Universitat Jaume I (Sales, Ferrández i Moliner, 2012).

Es tracta d'un instrument elaborat a partir de l'adaptació de l'Index for Inclusion de Booth i Ainscow (2000), i de les escales d'observació per a contextos interculturals d'Aguado i col·laboradors (2003). Consta de tres dimensions, en les quals s'indiquen una sèrie de factors clau per a l'autoavaluació escolar. En cada factor s'introdueixen una sèrie de preguntes de reflexió per poder realitzar una primera exploració de la realitat arreplegant evidències i, en una segona fase, en què la comunitat educativa puga prendre decisions sobre les dimensions i factors seleccionats en els factors desitja centrar els seus processos de millora.

Aquesta guia s'incorpora a la proposta de diagnòstic social participatiu, en el qual participa tota la comunitat educativa. Els factors arreplegats en la Guia CEIN orienten aquest procés comunitari i democràtic, i assenyalen l'enfocament inclusiu i intercultural dels canvis.

El procés de construcció de l'escola consisteix precisament a generar un projecte compartit que arreplega els desitjos i les inquietuds individuals, i els va transformant en un relat compartit, a partir de la creació d'espais de reflexió, creativitat, presa de decisions democràtiques i acció col·laborativa. La Guia CEIN proporciona qüestions per al debat i la presa de decisions entorn de les dimensions i factors clau següents:

Dimensió A: Qui som i com ens veiem i ens veuen?

A.1. Valors compartits: Sabem cap a on volem que vaja el nostre centre? Evitem el racisme, sexisme, classisme, homofòbia, actituds contra la discapacitat i altres formes de discriminació? 
A.2. Valoració positiva de la diversitat: Es veu la diversitat com un repte per a la millora del centre i no pas com un problema? Les desigualtats generades per les diferències culturals, de gènere, socioeconòmiques i de capacitats són contrarestades en la marxa quotidiana del centre?

A.3. Altes expectatives: Es fa explícita l'alta expectativa que es té de l'alumnat, famílies i professorat?

Dimensió B. Com ens organitzem?

B.1. Projecte educatiu intercultural inclusiu: El projecte educatiu i altres documents oficials arrepleguen clarament la voluntat intercultural inclusiva del centre?

B.2. Lideratge inclusiu: Es proporciona a tota la comunitat l'oportunitat equitativa d'influir en les decisions, pràctiques i polítiques de l'escola?

B.3. Cultura col-laborativa: Es potencien les xarxes de suport entre col-legues (del centre i d'altres centres) i els suports sociocomunitaris (famílies, associacions, voluntariat...)?

B.4. Temps i espais per a la reflexió i la innovació: S'estableix un espai i temps comú per planificar accions i per al suport i l'assessorament?

B.5. Comunicació i mediació intercultural: Es té consciència que no totes les persones usen els mateixos patrons comunicatius, es coneixen els aspectes que dificulten la comunicació i se sap com millorar-la?

B.6. Participació de la comunitat: Els membres de la comunitat participen igualment en el centre independentment de la seua procedència, gènere, estatus social i/o capacitats?

Dimensió C. Com aprenem i ensenyem?

C.1. Agrupaments heterogenis: El criteri bàsic per crear grups classe i de treball és l'heterogeneïtat (gènere, llengua, capacitats, interessos, ritme)?

C.2. Objectius i continguts curriculars per competències: Es planifica l'aprenentatge de conceptes, procediments i actituds conjuntament en forma de competències?

C.3. Metodologia participativa i cooperativa: Es fomenta que l'alumnat assumisca la responsabilitat del seu propi aprenentatge?

C.4. Activitats globalitzadores: Es potencien les activitats que permeten globalitzar el coneixement adquirit?

C.5. Avaluació diversificada: S'utilitzen una varietat d'estratègies d'avaluació que permeten a tot l'alumnat mostrar les seues habilitats i guiar el seu procés d'aprenentatge?

C.6. Gestió dialógica de l'aula: L'ambient, organització i recursos de l'aula contribueixen a l'autonomia i responsabilitat de l'alumnat?

C.7. Competències de comunicació intercultural del professorat: Coneix i té en compte els diferents patrons comunicatius (to, temes, proximitat, tabús, gestos...?

C.8. Desenvolupament professional i comunitari: El professorat i els membres de la comunitat es responsabilitzen d'avaluar les seues pròpies necessitats d'aprenentatge? 
Així doncs, el DSP orientat per les reflexions que aporta la Guia CEIN es desenvolupa al llarg del curs, i genera un procés democràtic, inclusiu i intercultural que permet l'anàlisi compartida, la presa de decisions cooperativa i la reflexió sobre l'acció en un flux constant de repensar la pràctica i construir un model d'escola i comunitat entre tots (Aguirre, Escobedo i Sales, 2014).

\subsection{Ciutadania crítica i educació intercultural: moviments de transformació social}

La ciutadania crítica apel·la al compromís i la implicació activa, a la reflexió i la participació, des d'un lideratge inclusiu. Com apunta Gimeno Sacristán (2001), les noves formes d'entendre la ciutadania impliquen noves esferes de decisió que és necessari democratitzar amb la participació dels ciutadans, estructurant moviments amplis imprescindibles per intervenir en els processos de globalització. Cal adquirir consciència com a éssers interculturals o mestissos i admetre-ho com quelcom enriquidor. Aquest és un tret de maduresa i fortalesa cultural, davant de la feblesa que produeix l'aïllament. Per això, la formació d'una ciutadania crítica, que legitima la funció globalitzadora més universal d'un projecte pedagògic parteix del diàleg democràtic, la participació igualitària crítica i compromesa amb la transformació social, i potencia la millora educativa des de la recerca-acció i la reflexió sobre la pròpia pràctica (Elliot, 2011).

Exercir la ciutadania crítica en l'àmbit educatiu significa «sentir-se acompanyat i compartir el coneixement, problematizar i renegociar significats i pràctiques, planificar accions i mesures per transformar i millorar la realitat, observant i reflexionant sobre aquesta». Així, per exemple, del moviment $15 \mathrm{M}$, com a moviment social participatiu, ens queden algunes bones idees per a la formació de la ciutadania crítica: la necessitat de crear espais i temps per al diàleg igualitari i la participació; l'ús de procediments democràtics com la combinació entre assemblees plenàries $\mathrm{i}$ el treball en comissions; entendre el món com una complexitat on tots els temes i persones estan interconnectats (economia, política, educació, art, ecologia); el sentiment de pertinença a un grup que creu possible canviar aquest món complex, un sentit de responsabilitat històrica, i d'ocupar-se dels assumptes públics (de la polis, a l'àgora).

La ciutadania crítica evidencia la necessitat d'obrir nous diàlegs, que ens porten a mons encara inexplorats, que ens permeten construir una cultura col-laborativa i acabar progressivament amb l'aillament i la inseguretat que aquest produeix. Temps i espai per a nous temes, nous canals de comunicació, nous interlocutors amb diverses experiències i perspectives que enriquisquen el treball diari i permeten transformar la pràctica de manera autèntica.

Es tracta d'un procés d'indagació col·laborativa que permet transformar la realitat social a través d'accions socioeducatives globalitzades que emfatitzen el protagonisme dels agents socials de l'entorn amb la dinamització i el compromís de la 
comunitat. El seu objectiu és millorar el procés d'ensenyament-aprenentatge com a procés dialògic, democràtic, ètic i global (Moliner, Sales i Traver, 2007).

De la mateixa manera, els projectes que el grup MEICRI hem emprès des de la Universitat Jaume I en els últims cinc anys, seguint els pressupostos de la investigación-acció participativa, pretenen desenvolupar processos d'innovació i millora en els centres escolars, des de la col-laboració i el compromís amb el propi territori i amb els seus agents educatius i comunitaris (Sales, Moliner i Traver, 2010).

Així doncs, la millora i el canvi escolar cap a una ciutadania crítica sorgeixen quan donen sentit a les crisis i els somnis individuals, dins d'un projecte inclusiu $\mathrm{i}$ intercultural que ens fa pertànyer a una comunitat que vol ser més equitativa $i$ solidària. Podríem parlar de tres grans pilars per construir una ciutadania crítica des de moviments de transformació inclusiva i intercultural: Partir del que som, saber organitzar-nos i canviar el que fem (Sales, 2012). Les tres dimensions que arreplega la Guia CEIN per ajudar a orientar processos de transformació.

\subsubsection{El canvi ve a partir del que som}

La construcció de la ciutadania crítica ha de partir del que cadascú és, del que l'interpel·la i l'emociona. La necessitat de canvi ha de ser reconeguda per tota la comunitat educativa. No es tracta d'un procés imposat de dalt a baix (top-down), sinó que ha de ser dirigit des de dins de la mateixa institució. La presa de consciència ha d'implicar tota la comunitat i reflectir la pluralitat de visions per cercar alternatives inclusives $\mathrm{i}$ interculturals al fracàs i l'exclusió social.

Viure la situació inicial com una crisi personal i professional que es desitja superar és un primer pas per assumir que el conflicte intern té una solució compartida amb uns altres. El desig de fer-ho millor, de millorar les relacions i la convivència, porta a un grup a plantejar-se què fer, quins camins seguir, com resoldre problemes i conflictes que es perceben no solament personals sinó que concerneixen a tots $\mathrm{i}$ totes. D'aquesta crisi personal a la recerca d'un somni compartit sorgeixen projectes de canvi escolar que creuen en la construcció d'una ciutadania crítica, creant xarxes (Sales, 2012).

Negociar les situacions de resistència i treballar junts per al canvi genera un empoderament com a agents d'aquest canvi en tots, ja que són més conscients de la seua capacitat d'intervenció, de les expectatives d'èxit i del reconeixement públic rebut per part dels altres (Gill i Chalmes, 2007). Així doncs, aquesta millora de l'autoestima millora al seu torn l'eficàcia i les expectatives sobre la possibilitat de canvi, per la qual cosa l'empoderament té una doble dimensió: emocional i ètica, i legitima el professorat i la comunitat a prendre les regnes del canvi. Aquesta és una poderosa conseqüència d'aquests processos de construcció de ciutadania crítica a través del canvi: la millora de la confiança, el respecte mutu, les altes expectatives i l'augment de la sensibilitat cap a la diversitat i la complexitat de les identitats. 
I d'aquesta forma, partim del que som i d'allò que ens fa sentir capaços de fer i ser el que volem. Cerquem formes d'organitzar-nos amb uns altres per crear massa crítica suficient per a un canvi global (Sales, 2012).

\subsubsection{Desenvolupant cultura col-laborativa: canvis organitzatius}

El que realment converteix cada persona en un ciutadà crític no és la possibilitat de canvi individual, sinó la capacitat de ser agents d'un canvi social, d'una transformació col·lectiva. En aquest sentit, el procés de canvi serà inclusiu i intercultural si és un procés democràtic i participatiu, és a dir, si generem una cultura col·laborativa.

Són necessaris espais i temps per a la reflexió col·lectiva: reunions, assemblees comunitàries... Llocs i horaris per al debat, l'anàlisi, l'exploració de problemes i la resolució de conflictes a través del consens (Cox i Robinson-Pant, 2008). Temps específic per construir equip i trencar l'individualisme i les resistències d'altres companys i companyes que no s'atreveixen a innovar. Temps per mostrar bones pràctiques i contagiar amb la implicació personal i les satisfaccions obtingudes.

Significa passar d'una cultura de formació individualista i gremialista a una altra de dialògica i comunitària. Aquest canvi de cultura, com hem vist, afecta les relacions de poder, i suposa la creació de procediments i espais per al debat, la negociació i la participació democràtica.

La cultura col'laborativa que es desenvolupa en els processos de canvi que hem assessorat sorgeix del reconeixement de la pluralitat de veus i de la idea d'escola com a comunitat d'aprenentatge. La diversitat es valora com un factor valuós per a la transformació, i el diàleg intercultural es converteix en eina d'aprenentatge i de construcció social del coneixement (Armstrong i Moore, 2004).

El desenvolupament de comissions mixtes i assemblees com a estratègies de participació democràtica representa un canvi significatiu cap a una cultura escolar intercultural $\mathrm{i}$ inclusiva. Una segona conseqüència, derivada de la posada en pràctica d'estratègies de participació horitzontal, és el desafiament a la seua estructura vertical i als estils de gestió directius, és a dir, a les relacions de poder prestablertes. Les sessions de formació compartida, de reflexió comunitària, les reunions de les comissions, els debats en les assemblees, proporcionen espais per a l'aprenentatge dialògic en els quals la presa de decisions es fa més democràtica i igualitària, basada en un enfocament sociocomunitari de l'escola com a organització (Jiménez i Pozuelos, 2001). El repte de futur és assegurar la sostenibilitat dels canvis incipients a través de la institucionalització i la consolidació d'un procés d'investigació-acció participativa com a procés d'autogestió de la millora i del desenvolupament professional i comunitari (Hargreaves i Fink, 2006).

El pas d'una cultura individualista cap a una cultura col-laborativa té tres elements clau que emergeixen de l'anàlisi dels estudis de cas (Traver, Sales i Moliner, 2010): 
a) Assumir el projecte com a propi de tota la comunitat educativa. Viure-ho de forma parcel·lada o identificar-ho més amb un col·lectiu que amb uns altres és una gran dificultat per al diàleg igualitari i la cerca d'enteniment i consens des de la força dels arguments i no del poder.

b) Pluralitat de veus: respecte, tolerància i empatia. El professorat ha d'aprendre a decidir escoltant totes les veus. També les minories són importants, tots els col·lectius i persones ho són, si s'integren les seues propostes en un objectiu compartit.

c) Trasparència informativa $\mathrm{i}$ avanç des del disens: la implicació de tota la comunitat educativa requereix estar informats, comprendre la realitat en la seua complexitat per poder prendre decisions que no sempre són fàcils de consensuar. La confiança i la coresponsabilitat són fonamentals.

Per això, en la construcció de la ciutadania crítica a través del desenvolupament d'una cultura col·laborativa, s'emfatitza la importància d'aprendre estratègies i tenir recursos per facilitar l'autoavaluació cooperativa i la presa de decisions democràtica, dos elements clau per a la reflexió crítica i el qüestionament col·lectiu de les pràctiques d'exclusió i racisme (Benjamin, 2002).

\subsubsection{Construïm ciutadania canviant les nostres pràctiques}

El que es percep com a transformació en els contextos socioeducatius poden ser petits canvis que impliquen, per exemple, provar estratègies de comunicació o aprenentatge diferents; crear grups de suport que donen seguretat i eviten l'aïllament i la solitud davant les crisis; compartir el que se sap fer; formar-se en grup (comunitat), experimentar i avaluar. Aquests canvis en les pràctiques socials i educatives ens porten a un canvi en la cultura de la institució o el context en el qual estiguem treballant (Moliner, Sales i Escobedo, 2016).

Es tracta que els petits canvis puguen provocar grans transformacions, si sabem en quin context global tenen sentit i quin impacte estructural suposen (Elliott, 2011). En algunes institucions els canvis metodològics, d'agrupaments, de suports, d'organització del personal, han fet visible la part organitzativa i estructural que calia modificar i que s'havia quedat invariable en altres projectes prèviament desenvolupats.

Els canvis macro es veuen lluny, difícils i desmotiven. Aquesta sensació d'impotència es comença a alleujar quan es troben espais col·lectius de participació com a seminaris, grups de treball, xarxes de suport, projectes col-laboratius o comunitats de pràctica. Per tant, el gran pas del petit canvi cap a un projecte comunitari de ciutadania crítica depèn de la capacitat i la voluntat de cada individu d'implicar-se amb l'entorn i els canvis socials des del seu espai quotidià, el seu territori habitual (Moliner, Sales i Escobedo, 2016). 
Cada petit canvi, cada espai transformat, va formant part d'una concepció collaborativa de canvi més global, d'escenari futur de millora, quan el lideratge de l'acció participativa és compartit i el canvi és sostenible.

El focus, des de la psicopedagogia i l'educació en general, se centra a analitzar i valorar les dimensions i els factors que poden propiciar un canvi cap a la ciutadania crítica en l'àmbit socioeducatiu, des del dia a dia i les possibilitats i potencialitats que els grups humans, els col·lectius, cada persona individualment, detecten i desenvolupen, des de negociació i resolució de conflictes, com a estratègia i eina per consensuar mínims de convivència i d'indagació col·laborativa de la comunitat (Gather, 2004; Abril i altres, 2009).

D'aquesta forma és possible retornar als éssers humans el protagonisme que mai haurien d'haver perdut en el camí dels sistemes educatiu i social cap a la transformació i la millora personal i social. En cas contrari, els mitjans de control associats al poder acaben substituint la comunicació realitzada per mitjans no verbals, i es desemboca en la burocratització de les decisions (Arnáiz i Guirao, 2015). La lògica i la cerca d'eficàcia de les accions orientades a l'èxit finalment fa desaparèixer dels espais de participació comunitària la lògica pròpia de l'acció que cerca l'enteniment, de l'acció comunicativa (Traver, Sales i Moliner, 2010).

En funció de com definisca i entenga el concepte de comunitat, el grau d'obertura i de relacions amb el propi territori, i les vies, els tipus de participació i els elements sobre els quals participar, les relacions en el context variaran de forma significativa. Els nous requeriments de la societat globalitzada exigeixen que famílies, educadors i legisladors es plantegen seriosament com preparar la gent per a la seua participació activa i crítica com a ciutadans i ciutadanes del segle XxI. En aquest sentit, creiem que l'escola, com a context socioeducatiu, és un àmbit privilegiat per desenvolupar aquest concepte de comunitat democràtica i intercultural, i convertir-se en un model organitzatiu transportable a l'organització de tota la societat civil, i per tant, en un agent actiu de la reconstrucció social. Això vol dir que si la societat civil participa en l'escola per fer-la veritablement intercultural i, per tant, democràtica (en la presa de decisions, en la definició de les finalitats, articulant les relacions, proposant models culturals), l'escola es converteix al seu torn en una unitat global de canvi. D'aquesta forma connecta l'àmbit micropolític de l'aula i l'escola amb el macropolític, de la societat complexa, mestissa i global, i ens inserta en xarxes de suport i comunicatives que són, al seu torn, en el seu desenvolupament i objectiu, interculturals i inclusives. Que parteixen del que som $i$ ens sentim cadascun de nosaltres, que ens fan compartir amb altres persones els nostres somnis, $\mathrm{i}$ ens porten junts a explorar territoris desafiadors $\mathrm{i}$ estimulants de ciutadania crítica (Sales, 2012). 


\section{Activitats de reflexió-acció}

a) Análisi de les pedagogies invisibles d'un espai de la pròpia universitat

Organizats en petits grups, escollim un espai de la universitat per analitzar:

- Violència simbòlica

- Currículum opac

- Direccionalitat

- Performativitat

Es redacta un petit relat etnogràfic de l'experiència del grup en aquest espai i es fan propostes de transformació de l'espai des d'un plantejament intercultural:

- Canvis en la direccionalitat i la performativitat

- Canvis físics: implicacions pedagògiques

- Canvis en les relacions entre participants aquest espai

Els diferents relats seran compartits a classe per constrastar els elements que s'hi han trobat i organitzar-se col-laborativament per portar a terme les transformacions d'un context seleccionat pel grup.

b) Desenvolupament de projectes d'investigació-acció participativa en entitats socioeducatives reals. Els detalls i les directrius dels projectes es pengen a l'aula virtual del curs per a l'organització dels grups de treball.

\section{Lectures recomanades}

Acaso, M. (2012): Pedagogías invisibles. El espacio del aula como discurso, Madrid, Catarata.

LAtorre, A. (2003): La Investigación acción: Conocer y cambiar la práctica educativa, Barcelona, Graó.

SagÁstegui, D. (2004): Una apuesta por la cultura: el aprendizaje situado, Sinéctica, 24, 30-39.

Velasco, H. i A. DíAz (1997): La lógica de la investigación etnográfica. Un modelo de trabajo para etnógrafos de la escuela, Madrid, Trotta.

\section{Recursos web recomanats}

Web de María Acaso: http://www.mariaacaso.es/.

Blog del Seminari de Ciutadania Crítica: http://ciutadaniacritica.blogspot.com.es/.

Web Grup Investigació MEICRI: http://meicri.uji.es/. 


\section{Referències}

ABRIL, T. i altres (2009): Escuela y territorio. Experiencias desde los centros y desde la comunidad, Barcelona, Graó.

Acaso, M. (2012): Pedagogías invisibles. El espacio del aula como discurso, Madrid, Catarata.

Aguado, T. i altres (2003): «Cultural Diversity and School Equity. A Model to Evaluate and Develop Educational Practices in Multicultural Education Contexts», Equity \& Excellence in Education, 36 (1), 50-63.

Aguirre, A. (2012): Diagnóstico social participativo, desarrollo local y participación social: un estudio de caso sobre participación juvenil en la Comarca d'Els Ports. Trabajo de investigación, Castelló de la Plana, Universitat Jaume I (material inèdit).

Aguirre, A., A. Sales i P. Escobedo (2014): «Construyendo la escuela intercultural inclusiva desde el diagnóstico social participativo», XI Congreso Internacional, XXXI Jornadas de Universidades y Educación Inclusiva: «La escuela excluida», Castelló de la Plana, Universitat Jaume I.

AlBerich, T. i altres (2009): Manual de metodologías participativas, Madrid, Red CIMAS.

Armstrong, F. i M. Moore (2004): Action Research for Inclusive Education: Changing Places, Changing Practices, Changing Minds, Londres, Routledge Falmer.

Arnáiz, P. i J. M. Guirao (2015): «La educación intercultural en una escuela inclusiva. Vías para reorientar el camino», dins A. Escarbajal (ed.) (2015): Comunidades interculturales y democráticas. Un trabajo colaborativo para una sociedad inclusiva, Madrid, Narcea, 53-62.

BARHAM, A. i O. Fals Borda (1992): «La situación actual y las perspectivas de la IAP en el mundo», dins SAlAZAR, C. (1992): La investigación acción participativa. Inicios y desarrollos, Madrid, Editorial Popular.

BARTOLOMÉ, M i R. Acosta (1992): «Articulación de la educación popular con la educación formal. Investigación participativa», Revista de Investigación Educativa, 20, 151-178.

Benjamin, S. (2002): The micropolitics of inclusive education, Buckingham, Open University Press.

Bermejo, L., J. Lobillo i C. Molina (2004): «Aportes del DRP (Diagnóstico rural participativo) a las metodologías participativas y aplicación a la gestión de los recursos naturales de la Gomera», dins EncInA, J. (2004): Praxis participativas desde el medio rural, Madrid, Iepala Editorial.

Bоoth, T. i M. Ainscow (2000): Guía para la evaluación y mejora de la educación inclusiva, traducido y adaptado por traducción y adaptación: Ana Luisa López, David Durán, Gerardo Echeita, Climent Giné, Esther Miquel, Sebastián Moratalla y Marta Sandoval, Madrid, CSIE y Consorcio Interuniversitario para la Educación Inclusiva.

Butler, J. (2007): El género en disputa: el feminismo y la subversión de la identidad, Barcelona, Paidós.

Cox, S., i A. Robinson-PAnt (2008): «Power, participation and decision making in the primary classroom: children as action researchers», Educational Action Research, 6 (4), 457-468. 
Deltoro, E. (2006): Cómo trabajar con adolescentes en el tiempo libre, Saragossa, Libros Certeza.

Elliott, J. (2011): «Educational Action Research and the Teacher», Congreso Internacional de Mejora Educativa y Ciudadanía Crítica, Quaderns Digitals.net, 69, disponible en http://www.quadernsdigitals.net/index.php?accionMenu=hemeroteca. VisualizaNumeroRevistaIU.visualiza\&numeroRevista_id=824\&PHPSESSID $=7 \mathrm{a} 9 \mathrm{ab}$ f552f7f16fc53ffe $317260 \mathrm{e} 6 \mathrm{~d} 65 \%$.

Ellsworth, E. (2005): Posiciones en la enseñanza. Diferencia, pedagogía y el poder de la direccionalidad, Madrid, Akal.

FERNÁNDEZ SiERRA, J. (coord.) (2013): Transitar la cultura. Niños y niñas inmigrantes en la educación obligatoria. Estudios de caso. Multicaso, Màlaga, Aljibe.

Fontcuberta, J. (2010): A través del espejo, Madrid, La Oficina.

GArcía, R. i al. (2000): Necesari@s, Madrid, FAD. Ministerio de trabajo y asuntos sociales.

GATHER, M. (2004): Innovar en el seno de la institución escolar, Barcelona, Graó.

Gill, H., i G. Chalmes (2007): «Documenting diversity: an early portrait of a collaborative teacher education iniciative», Internacional Journal of Inclusive Education, 11 (5-6), setembre-novembre, 551-570.

Gimeno SACRISTÁN, J. (2001): Educar y convivir en la cultura global, Madrid, Morata.

Habegger, S. i I. Mancila (2006): «El poder de la Cartografía Social en las prácticas contrahegemónicas o la cartografía social como estrategia para diagnosticar nuestro territorio», disponible en http://areaciega.net/index.php/plain/car tografias/car_tac/el_poder_de_la_cartografia_social.

Jiménez, J. R. i J. Pozuelos (2001): «Una escuela pública abierta a la comunidad», Investigación en la escuela, 44, 5-17.

LATORRe, A. (2003): La Investigación acción: Conocer y cambiar la práctica educativa, Barcelona, Graó.

LaVE, J. (1991): La cognición en la práctica. Barcelona: Paidós.

Lave, J. i E. Wenger, E. (1999): Situated learning: legitimate peripheral participation, Cambridge, Cambridge University Press.

Martínez, A. (1995): El diagnóstico participativo: una herramienta de trabajo para las comunidades, Costa Rica, Catie.

Moliner, O., A. Sales i J. Traver (2007): «Procesos de indagación colaborativa: investigación-acción y apoyo entre colegas para una educación intercultural e inclusiva», Congreso de Orientación Educativa y Profesional, Quaderns Digitals.Net, disponible en http://www.quadernsdigitals.net/index.php? accionMenu=hemeroteca.VisualizaArticulosu.visualiza\&articulo_id=10390.

Moliner, O., A. Sales i P. Escobedo (2016): «Posibilidades y limitaciones de generar cultura de centro desde las prácticas compartidas de aula: el caso de la educación intercultural inclusiva», Estudios sobre Educación, 30, 51-70.

SagÁstegui, D. (2004): Una apuesta por la cultura: el aprendizaje situado, Sinéctica, 24, 30-39.

Sales, A. (2012): «Creando redes para una ciudadanía crítica desde la escuela intercultural inclusiva», Revista de Educación Inclusiva, 5 (1), 51-68.

Sales, A., O. Moliner i J. Traver (2010): La construcción de la escuela intercultural inclusiva desde procesos de investigación-acción, Castelló de la Plana, Servei de Publicacions de la Universitat Jaume I. 
Sales, A., O. Moliner i J. Traver (eds.) (2010b): La construcción de la escuela intercultural inclusiva desde procesos de investigación-acción, Castelló de la Plana, Servei de Publicacions de la Universitat Jaume I.

Sales, A., R. Ferrández i O. Moliner (2012): «Escuela intercultural inclusiva: estudio de caso sobre procesos de autoevaluación», Revista de Educación, 358, 153-173.

Traver, J., A. Sales, A. i O. Moliner (2010): «Ampliando el territorio: Algunas claves sobre la participación de la comunidad educativa», Revista electrónica iberoamericana sobre calidad, eficacia y cambio en educación, 3 (8), 97-119.

Velasco, H. i A. DÍAz (1997): La lógica de la investigación etnográfica. Un modelo de trabajo para etnógrafos de la escuela, Madrid, Trotta.

VyGotsky, L. S. (1973): «Aprendizaje y desarrollo intelectual en la edad escolar», VV. AA. Psicología y Pedagogía, Akal, Madrid.

Wenger, E. (2001): Comunidades de práctica. Aprendizaje, significado e identidad, Barcelona, Paidós.

Woods, P. (1987): La escuela por dentro: la etnografía en la investigación educativa, Buenos Aires, Editorial Paidós. 


\section{Pràctiques interculturals: prejudicis, comunicació i relacions quotidianes}

\section{Introducció}

El tercer i últim bloc se centra en les pràctiques educatives que permeten gestionar la diversitat des d'aquest enfocament intercultural. Un cop aclarits els conceptes i els models, descrites les eines i les estratègies d'anàlisi del context, ens apropem a diferents àmbits socioeducatius als quals poder intervenir de manera intercultural.

a) La construcció de la identitat cultural i la formació d'actituds interculturals, amb propostes didàctiques per previndre i eliminar prejudicis i estereotips cap a la diversitat cultural de tot tipus. S'hi presenten i analitzen programes i recursos que fomenten una identitat múltiple i oberta a una societat global i mestissa al temps que hi facilitem l'ensenyament d'actituds de diàleg, respecte i solidaritat per a l'intercanvi cultural i la lluita contra el racisme i l'exclusió.

b) Comunicació intercultural i multilingüisme: estratègies comunicatives que propicien la interculturalitat en contextos multiculturals i multilingües. S'hi analitzen els elements de la comunicació i els diferents programes d'educació bilingüe i multilingüe i les seues implicacions socioeducatives.

c) Pràctiques educatives que tinguen en compte la interacció entre gènere, cultura i classe social, des de la teoria asincrònica de Cameron McCarthy i la pedagogia crítica. Tenint en compte que la identitat és múltiple i dinàmica, l'avaluació, la intervenció i l'orientació psicopedagògiques de la diversitat cultural es plantegen des de la gestió d'aquesta complexitat i la hibridació, més que des de categories tancades i estanques que es fonamenten en la teoria del dèficit. S'hi presenten programes, experiències, projectes i recursos que tenen en compte aquesta mirada transversal, com per exemple, l'anàlisi crítica de productes audiovisuals i mediàtics amb enfocament intercultural i ús educatiu. O la creació d'espais informals d'aprenentatge que qüestionen relacions sexistes, racistes i classistes. 


\subsection{Eliminant prejudicis. Programes de formació d'actituds interculturals}

Una possible línia de treball des de la psicopedagogia són els programes de formació d'actituds interculturals. Per fonamentar-los mínimament, hem d'aclarir els conceptes bàsics d'actitud, estereotip i prejudici.

L'actitud és una predisposició apresa per respondre consistentment d'una manera favorable o desfavorable cap a un objecte social determinat (Fishbein i Ajzen, 1975). D'aquesta definició podem extraure les característiques fonamentals que distingeixen l'actitud d'altres conceptes: es diferencien de les creences perquè aquestes són associacions o connexions que les persones estableixen entre un objecte i diversos atributs, per la qual cosa la seua dimensió essencial és cognitiva, mentre que la característica central de l'actitud és l'avaluativa-efectiva (Eagly i Chaiken, 1993). Es diferencien dels valors en el fet que aquests són un tipus de creences prescriptives que ocupen un espai central en l'estructura de la personalitat i es refereixen a allò que hauria o no hauria de fer. Són ideals abstractes, mentre que l'actitud sempre és una preferència o rebuig cap a un objecte social concret. Per tant, l'actitud suposa una disposició a actuar, és a dir, té a més d'un component cognitiu, les creences sobre l'objecte; un component afectiu, els sentiments cap a l'objecte i els seus atributs, i consta d'un component conductual, tot tipus de resposta o curs d'acció amb què es manifesta l'actitud cap a un objecte, situació, persona o grups en qüestió (Stangor et al., 1991).

El prejudici ha sigut definit com «una actitud hostil o aversiva cap una persona que pertany a un grup, pel fet de pertànyer-hi, i se li atribueixen, a més a més, les qualitats rebutjables adscrites al grup» (Allport, 1992:7). Per tant, la sobregeneralització i l'hostilitat cap a certs grups són les característiques del prejudici com a actitud.

No hem de confondre prejudicis i estereotips. Els estereotips constitueixen el contingut cognitiu del prejudici. Es tracten de creences rígides i sobregeneralitzades sobre els atributs associats als membres d'un grup (Aboud, 1994). Els estereotips formen part del procés cognitiu de categorització pel qual emmagatzemem la informació en categories socials com una manera d'interpretar la realitat. Encara que la categorització és un procés humà natural, en el cas de la estereotipació, la informació s'inclou en categories massa inflexibles, que es mantenen tot i que se n'evidencia empíricament la inadequació. Per tant, l'estereotip és una generalització, no contrastada, que influeix, una vegada elaborada, en la forma en què seleccionem i processem la informació sobre determinats grups socials i culturals (Hewstone i altres, 1994).

L'estereotip serveix per racionalitzar els sentiments negatius cap a determinats grups culturals, reforça l'avaluació afectiva negativa que se'n fa i justifica les conductes respecte a aquests en un context històric i ideològic determinat. 
Aquestes conductes racistes, com a manifestació del prejudici, poden anar des de l'expressió verbal de l'antagonisme, per exemple jugant amb la ironia i els estereotips; l'evitació dels membres del grup; la discriminació, és a dir, excloure'ls de certs drets socials o privilegis per pertànyer a un grup cultural determinat; $i$ arriba a l'atac físic i fins i tot, en els casos més dramàtics i de màxima expressió de la violència, a l'extermini del grup (Ponterotto i Pedersen, 1993).

Els orígens i factors causants del prejudici, concebut com una actitud social, han sigut explicats des de teories tant sociològiques com psicològiques, cadascuna de les quals ha fet més ressò en uns o altres factors com a determinants d'aquest prejudici.

Factors sociolòics: les teories sociològiques estan d'acord que en les societats estratificades es dóna una distribució desigual de poder i estatus entre els diferents grups culturals, la qual cosa porta, d'una banda, a una competició pels béns socials i econòmics que crea conflicte d'interessos i, d'altra banda, genera uns valors socials atribuits a cada grup que es veuen reflectits en els prejudicis. En el procés de socialització s'aprenen aquests valors, sobretot a través de la família, de manera que es reprodueixen generació rere generació, i exerceixen així un control social. Siga per raons històriques, demogràfiques o institucionals, el prejudici s'origina en l'estructura social i política, i no depèn tant de la personalitat dels individus (Aboud, 1994).

Factors psicologics: des de la teoria sociocognitiva del prejudici (Aboud, 1994) s'explica la naturalesa del prejudici com un procés que, des de la infantesa, implica les dimensions afectiva, perceptiva i cognitiva, en un procés en paral·lel de desenvolupament cognitiu i moral, descrits per Piaget i Kohlberg, respectivament. Això vol dir que els desenvolupaments cognitiu, afectiu, social i moral estan profundament relacionats i que no podem explicar les causes del prejudici sense entendre totes aquestes dimensions interactuant de manera dinàmica.

Les teories sociològiques i psicològiques ens donen raons complementàries de l'existència dels prejudicis i del seu desenvolupament. Si bé les teories psicològiques ens permeten conèixer els mecanismes $i$ els processos individuals que potencien o redueixen els prejudicis, les teories sociològiques ens ofereixen l'explicació del context $\mathrm{i}$ les condicions socials que poden reforçar aquests prejudicis o eliminar-los.

\subsubsection{Programes de formació d'actituds interculturals}

Els mitjans de comunicació i altres agents de enculturació creen opinió i generen actituds que es reflecteixen en els comportaments socials, però es mouen per interessos que no sempre són ètics. Els programes de formació d'actituds interculturals són una eina pedagògica per analitzar els valors de la nostra societat $i$ educar ciutadans reflexius, crítics i lliures de manipulació. 
L'ensenyament-aprenentatge d'actituds té un fort impacte social, ja que permet desenvolupar predisposicions davant una societat en constant i vertiginós canvi cultural, on els coneixements i les conductes concretes queden ràpidament caducs.

Els programes de formació d'actituds interculturals consisteixen en un conjunt articulat d'activitats, a partir d'estratègies didàctiques d'aprenentatge cooperatiu, participació activa i comunicació persuasiva (Sales i García, 1997) per canviar actituds negatives cap a la diversitat cultural i generar actituds d'interculturalitat. Aquest objectiu central consisteix a canviar les actituds dels alumnes cap a la diversitat cultural, i propicia la informació i la formació necessàries perquè aquests qüestionen i canvien les seues creences estereotipades cap a persones d'altres cultures, i implicar-los activament en la formació de noves actituds de tolerància a la convivència multicultural, el respecte a la diferència i la predisposició a la cooperació i l'intercanvi cultural enriquidor.

Les estratègies didàctiques plantegen un qüestionament del tipus d'informació i de la manera en què aquesta s'elabora, interpreta i analitza, i de la relació entre professor/alumnes i entre alumnes perquè l'aprenentatge es convertisca en un procés actiu de crítica reflexiva dels models explicatius considerats fins al moment com els únics vàlids, cerca de noves perspectives, formes diferents d'entendre i interpretar el món en tota la seua diversitat, aprofitant el conflicte com a motor cognitiu d'aprenentatge, com el punt d'arrancada de la resolució de problemes, de presa de decisions a través del diàleg, el debat i la cerca de consensos que permeten les preses de posició individuals i col·lectives.

En cada context es defineix el programa a partir de l'objectiu que cal aconseguir, i de les estratègies que hi convé utilitzar, en funció de les actituds que es desitgen millorar o canviar. Desenvolupat en centres escolars, són els mateixos docents els responsables de l'elaboració i l'aplicació del programa. Ells estableixen els objectius dels seus respectius programes, segons el diagnòstic inicial, i trien les estratègies i tècniques que creuen que s'adeqüen més als continguts que imparteixen, als recursos de què disposen i al seu propi estil docent, a partir dels quals dissenyen les activitats que componen el programa i les seqüèncialitzen per desenvolupar-les a l'aula.

Seguint la filosofia del model intercultural, els programes es dissenyen per ser integrats dins del currículum ordinari i no pas com a activitat afegida o extraescolar, és a dir, que la seua planificació es realitza des de les àrees de coneixement en què van seran aplicats pels docents, a partir dels continguts curriculars i la programació temporal previstos per al curs, de manera que la formació d'actituds interculturals es convertisca en l'eix innovador del procés d'ensenyament-aprenentatge dins de la dinàmica habitual de l'aula. La temporalització mínima hauria de ser un trimestre, encara que es recomana programar activitats i revisar els continguts curriculars de tot el curs perquè els resultats siguen més positius i duradors en el temps. Així mateix, pot realitzar-se en una sola aula, però el recomanable és realitzar-ho en equip docent, de manera col-laborativa, en diferents nivells educatius i en totes les àrees curriculars d'un mateix centre escolar, la qual cosa augmenta l'eficàcia 
d'aquest tipus de programes i facilita la introducció de la perspectiva intercultural en l'organització i la cultura escolar, i trenca així les resistències institucionals i transforma les rutines docents (Sales i García, 1997).

\subsection{Comunicació intercultural i multilingüisme}

La comunicació intercultural, segons Rodrigo Alsina (1999: 19) «ha existit sempre que dues persones que es perceben a si mateixa com a membres de cultures diferents s'han intentat comunicar». Així doncs, si partim d'una concepció dinàmica de cultura i identitat cultural i som conscients de la necessitat de generar processos i contextos socioeducatius interculturals, hem de tenir present la importància de la comunicació intercultural i la necessitat de generar espais comunicatius en els quals es donen relacions de diàleg enriquidor, negociació de significats, construcció de coneixements compartits, es gestionen les relacions de poder i es transformen els conflictes de manera constructiva i inclusiva.

Com assenyala Trujillo (2005: 33-34), aquesta comunicació intercultural és un procés de conscienciació cultural» i «socialització rica». La «conscienciació cultural» (culture awareness) és el procés de presa de consciència de la presència de la cultura en tres plànols: consciència de la diversitat cultural de tota societat, on es creen, usen i gestionen símbols i significats (cultures), la qual cosa genera una rica matriu sociocultural (consciència de multiculturalitat). Consciència de la identitat múltiple de qualsevol persona com a resultat de múltiples experiències i situacions comunicatives (consciència de pluriculturalitat). Consciència que en cada situació comunicativa les convencions culturals per gestionar la interacció poden variar, i de la bona anàlisi d'aquests factors dependrà l'efectivitat i l'èxit comunicatiu (consciència d'interculturalitat). Respecte a la «socialització rica» (Trujillo Sáez, 2003), significa estar present en diferents contextos on es puga desenvolupar la conciència d'interculturalitat gràcies al contacte amb altres individus i comunitats.

Per aquest motiu ens plantegem la possibilitat, la necessitat $i$ els beneficis del multilingüisme en contextos educatius. El llenguatge forma part essencial de la cultura, no només perquè serveix de mitjà de comunicació interpersonal, sinó també perquè cada llengua expressa els valors, els significats i les cosmovisions del grup que la parla, i és un element, sovint fonamental, de la seua identitat com a grup cultural diferenciat. Aquesta connexió entre llengua i cultura és de vital importància per emprendre l'educació intercultural si partim que l'estudi de la llengua i la cultura ha d'entendre's des de la relació de les parts amb el tot, a través de models que expliquen les connexions internes i extralingüístiques i culturals. Ha de considerar-se també l'heterogeneïtat i el dinamisme dels grups lingüístics i culturals, és a dir, la seua capacitat de canvi i enriquiment continus. De fet, en el contacte intercultural s'aprecia al llarg de la història com els diferents grups s'influeixen mútuament i produeixen o lingüístiques entre dues o més llengües. Per això, des de la sociolingüística i la psicolingüística es pretén explicar aquestes situacions, per motius no solament intralingüístics, sinó, sobretot, per raons socials, 
psicològiques i culturals que determinen el desenvolupament del multilingüisme en condicions comunicatives reals. Des d'un es defineix la competència interaccional intercultural com: «la capacitat que poseeix una persona en situacions interaccionals per efectuar accions verbals i no verbals en dos papers, el de parlant i el d'oient, i d'acord amb les regles socioculturals i sociopsicològiques del grup» (Oksaar,1984:49).

Aquesta competència, com veiem, no és únicament lingüística, sinó que comporta conèixer el context social i cultural que condiciona una determinada conducta lingüística, és a dir, el seu «culturema». Per tant, aprendre una llengua significa també aprendre els elements extralingüístics que marquen el seu ús en diferents situacions comunicatives i que formen part essencial de la competència intercultural necessària perquè es done una satisfactòria comunicació (Oksaar,1984; Siguán i Mackey, 1989).

Aquest fet ha de ser considerat des de l'educació a la vista de les diferents teories psicològiques constructivistes (Vigotsky, Leontiev, Luria, Piaget) que han ressaltat el paper fonamental de la interacció social en el desenvolupament del llenguatge i l'íntima relació d'aquest amb el pensament, la qual cosa significa que el context sociocultural en el qual el nen se socialitza, del qual forma part l'educació, determina en gran manera la seua capacitat lingüística i cognitiva, com va demostrar també Bernstein (1989), que va distingir entre dos codis lingüístics diferents, el codi elaborat i el restringit, que al seu torn impliquen dues maneres molt diferents d'elaborar la informació i analitzar la realitat i que estan relacionats respectivament a contextos socioeconòmics molt distants, amb estils diversos de transmetre la seua cultura i amb valors i normes dispars.

En la majoria de casos, la convivència entre grups culturals queda influïda per l'idioma com a tret diferenciador. La necessitat més urgent per a l'enteniment d'aquests grups és generar, d'una manera o altra, la capacitat dels individus de funcionar en diferents llengües, és a dir, de ser bilingües.

Respecte als efectes positius o negatius del bilingüisme, no es pot parlar en termes absoluts. Depèn de les condicions en què aquest es desenvolupe. Podem distingir, seguint la conceptualització de Lambert (1984), dos tipus de bilingüisme: 1) el «bilingüisme additiu», segons el qual es compagina la llengua pròpia o primera llengua amb una segona, de manera que aquesta proporciona noves habilitats cognitives i socials a la primera, sense produir la seua deterioració; 2) el «bilingüisme substractiu», que significa abandonar la primera llengua per «submergir-se» en la segona, amb el consegüent menyscapte de la llengua materna. Podem concloure que la forma additiva afavoreix el desenvolupament equilibrat d'ambdues llengües, enriqueix les estratègies cognitives i enforteix l'autoconcepte, i augmenta l'autoestima, mentre que la forma sustractiva deixa desprotegit el subjecte per desposseir-li dels seus esquemes lingüístics i del seu mitjà de comunicació fonamental, i li crea una forta inseguretat i contradicció que minva els progressos que puga realitzar en ambdues llengües. No només impedeix el bilingüisme real, sinó que aconsegueix un monolingüisme a un alt cost (Cummins, 2008). 
La implicació d'aquesta distinció amb l'educació és directa, perquè orienta la manera d'articular la competència en dues o més llengües de la forma més ràpida $i$ satisfactòria, no solament sense efectes nocius per a l'individu sinó amb l'aportació d'avantatges cognitius, socials i afectives.

Si ens atenem a factors lingüístics, podem dir que les condicions necessàries perquè es produïsca aquest bilingüisme additiu depèn de la relació entre ambdues llengües, en el sentit que si la primera llengua, o llengua materna, té un bon desenvolupament $i$ els estímuls suficients per mantenir-se en l'entorn, servirà de base per a la introducció d'una segona llengua. És a dir, que la competència en la primera condiciona l'adquisició correcta de la segona. És el que Cummins (1981) va denominar competència lingüística a dos nivells de dificultat: un d'habilitats comunicatives interpersonals bàsiques que es pot adquirir en dos anys, i un segon nivell de competència lingüística cognitivoacadèmica, que costaria aconseguir entre cinc i set anys i que és la que s'exigeix primordialment al llarg de l'escolarització. La forma d'aconseguir aquestes competències lingüístiques en dues o més llengües ha creat controvèrsies entre els investigadors en relació a l'organització de l'educació bilingüe en les escoles multiculturals (Cummins, 2007, 2008; Coelho, 2007; Oller i Vila, 2008).

\subsubsection{Modalitats d'educació bilingüe}

Programes d'immersió: Consisteixen en l'escolarització ja des dels primers anys en la segona llengua, considerant aquesta la forma ideal d'aprendre aquesta llengua com si fóra pròpia, en un context estimulant i de manera natural. Aquests programes d'immersió tenen èxit, sense retards en el desenvolupament cognitiu ni deterioració de l'autoestima ni pèrdua de la identitat, i afavoreix actituds positives cap a la comunitat de parlants d'aquesta segona llengua i tot el seu entorn cultural, quan la llengua que queda exclosa de l'escola té un bon prestigi social i una alta funcionalitat, i quan famílies i professorat mostren una adequada disponibilitat $\mathrm{i}$ motivació (Siguán i Mackey, 1989; Oller i Vila, 2008).

No obstant això, no és un sistema adequat quan la llengua exclosa és minoritària $\mathrm{i}$ no troba els estímuls socials necessaris per aconseguir l'estatus i les funcions de la llengua escollida per l'escola. En aquest cas, el bilingüisme resultant és substractiu i acaba produint la desaparició de la llengua més feble. Aquesta immersió, a llarg termini, significa una assimilació lingüística.

Com a variant d'aquesta modalitat existeixen programes de «transició», en els quals es comença l'escolarització en la llengua materna i progressivament es va incorporant la segona llengua fins a aconseguir el seu ús en tot el currículum en dues modalitats: programes de curta durada ( 2 anys aprox.) i programes de llarga durada (fins a 6 anys) i infinitat de models per a la distribució d'ambdues llengües en l'horari i calendari escolar, depenent de la predisposició i existència de recursos materials i personals de cada escola. Aquests programes s'han considerat més oportuns en situacions de desigualtat entre les llengües, encara que l'objectiu és similar al de la 
immersió: aconseguir que tots parlen la llengua majoritària, sense preocupar-se que les minoritàries finalment es perden o es reduïsquen a l'àmbit privat (Siqués, 2008).

En la posició oposada ens trobem amb una sèrie d'autors que defensen els programes de «manteniment» de la llengua materna de les minories al llarg de tota l'escolaritat al costat de la introducció de la segona llengua, en un vertader sistema escolar bilingüe o multilingüe. Els arguments proposats apunten cap a la importància de la primera llengua com a fonament de la segona, com esmentàvem anteriorment, no només al començament de la seua escolarització, sinó en tots els nivells educatius, ja que un bilingüisme equilibrat no s'aconsegueix si ambdues llengües no són valorades tant en la família com en l'escola i utilitzades en situacions comunicatives i en tasques intel·lectuals (Baker, 2007; Geneese, 2008; Vila, 2012).

Diferents investigacions semblen demostrar que els xiquets de grups culturals minoritaris que mantenen la seua llengua i la seua cultura a l'escola tenen millor rendiment acadèmic que els que la perden i demostren menys confusió i ambigüitat sobre la seua habilitat d'aprenentatge. A més de produir uns beneficis evidents en els subjectes de grups minoritaris, l'educació bilingüe per tothom permet considerar la diversitat lingüística com un recurs i no com un dèficit que cal compensar, i s'evita així el que Nieto (1992) anomena el lingüicisme, semblant al racisme o el sexisme, que es produeix en les situacions d'immersió de les minories i que atribueix el fracàs escolar a les deficiències lingüístiques dels alumnes i del seu entorn familiar (Skutnabb-Kangas i Dunbar, 2010; Collier i Thomas, 2004). Dins dels programes de manteniment existeix el model bidireccional o dual (two-way), que organitza tot el currículum en ambdues llengües (la majoritària i la minoritària) per a tots els alumnes. Aquest model ofereix un fort potencial per a l'alt rendiment acadèmic de tots els estudiants, $i$ es redueix la distància social i les relacions desiguals entre la majoria i les minories. Encara que no hi ha molta recerca sobre aquest tipus de programes, els estudis realitzats han trobat una gran efectivitat lingüística i acadèmica entre ells (Baker, 2011).

Amb els programes bilingües i multilingües de manteniment es generen actituds positives cap a les diferents llengües, la qual cosa és essencial en l'aprenentatge no solament de la llengua sinó de la cultura també, ja que el component afectiu és fonamental en l'adquisició gratificant del llenguatge, alguna cosa que l'escola ha d'incorporar a l'enfocament centrat en el cognitiu que tradicionalment hi ha predominat en ella (Cumins, Brown i Sayers, 2007). Cal tenir en compte que les estratègies d'aprenentatge en una aula multilingüe no són les mateixes que en un aula monolingüe. Aquesta diversificació metodològica també és un factor clau d'enriquiment pedagògic i lingüístic en contextos de diversitat cultural (Wells i Haneda, 2009).

D'aquesta forma, el multilingüisme és gestionat com un recurs per a la interculturalitat, per facilitar la comunicació intercultural i afavorir la promoció de la justícia social i la igualtat d'oportunitats per a tots els grups culturals en una societat multicultural (Skutnaab-Kangas i Dunbar, 2010; Coelho, Oller i Serra, 2013). 


\subsection{Gènere, cultura i classe social en les relacions quotidianes}

Des de paràmetres economicists es pretén rendibilitzar l'educació homogeneïtzant tots els criteris de selecció cultural, entenent la igualtat d'oportunitats com una única oferta de continguts i estratègies per a tots els alumnes, i donant per suposada la neutralitat científica d'aquesta selecció. El conflicte i la diversitat cultural són considerades com a disfuncions que cal eliminar per mantenir la cohesió i l'equilibri social. Això ha portat a models educatius monoculturals als quals tots els alumnes, vingueren de la cultura, gènere o classe social que vingueren havien d'adaptar-s'hi.

Aquest enfocament funcionalista ha sigut durament criticat per la pedagogia crítica que ha destacat la utilització de la violència simbòlica que els grups de poder han exercit a través de l'educació, per mantenir la seua postura dominant en la jerarquització social i econòmica. L'educació i l'escola han tingut una funció més reproductiva que transformadora i han legitimat, a través del currículum ocult, els valors, continguts i normes dels grups socials i culturals en el poder (Kincheloe i Steinberg, 1999; Torres, 2011).

Des d'una perspectiva de la pedagogia crítica, acabarem aquest tema apuntant una línia de treball intercultural que recull els principals aportacions de la teoria del currículum, els estudis culturals i els enfocaments de transformació de conflictes.

Partim de les teories culturals sobre la desigualtat en l'escolarització que els autors com Apple (1996), McCarthy (1994) o Kincheloe i Steinberg (1999) han afegit a la clàssica anàlisi del conflicte de classes. D'aquesta manera s'incorpora la desigualtat racial i sexual a la crítica de l'estratificació social en les societats capitalistes i consideren el racisme i el sexisme, al costat del classisme, com a formes d'explotació i alienació institucional, que s'interrelacionen dinàmicament i es veuen reforçades a la cultura escolar que tracta de desarticular-les (estratègies de resistència a la cultura dominant) a través de l'individualisme, el sexisme i el racisme (McLaren i Kincheloe, 2008). Així, els conflictes entre els grups racials i culturals s'expliquen des de les relacions de poder que aquests mantenen dins de l'estructura capitalista. El canvi d'aquestes relacions passa per la lluita política i social dels grups de gènere, raça i classe social marginats a la recerca d'alternatives estructurals més justes i igualitàries. Cameron McCarthy (1994) critica certs plantejaments massa generals, estàtics i simplistes de la interacció entre la classe, gènere i raça, i les esferes de l'economia, la cultura i la política. Davant d'aquesta, que és incapaç de captar la dinàmica entre classe-raça-gènere a les escoles, aquest autor proposa la teoria de l'asincronia, segons la qual les relacions entre les minories i la majoria són de quatre tipus: de competició pels recursos i oportunitats; d'explotació, segons les demandes del mercat laboral; de dominació, mitjançant l'estratificació del poder, i de selecció cultural, amb estratègies d'exclusió/inclusió del grup dels continguts del currículum. 
L'aportació que em sembla fonamental d'aquesta teoria asincrònica és la introducció d'un principi articulador de la dinàmica de les relacions entre minories $i$ majoria. Aquest principi articulador és l'element impulsor del conjunt cap a un centre d'atenció per al conflicte, que en cada cas pot ser la raça, el gènere o la classe social. Això explica com en ocasions un grup racial pot dividir-se per antagonismes de classe o de sexe, la qual cosa fa adonar-se de la impossibilitat d'establir paral·lelismes monolítics en la interacció entre aquests tres principis articuladores (McCarthy, 1994).

Aquesta anàlisi crítica, que integra allò educatiu (micro) en allò social i polític (macro), permet entendre els mecanismes socials que fonamenten qualsevol pràctica educativa. Malgrat això, com bé diu McCarthy, el racisme és molt anterior al capitalisme i no pot explicar-se des dels mateixos paràmetres que la classe social. Diguem que el capitalisme afegeix a la desigualtat de classe, la desigualtat de sexe i de raça que eren anteriors a aquest, però que s'encaixen perfectament a l'estratificació que desitja el capitalisme i que li és propícia per al seu desenvolupament i manteniment, ja que el sistema capitalista és per definició un sistema que genera desigualtat.

Això implica la necessitat d'una consciència històrica que permeta conèixer les connexions que al llarg de la història s'han donat entre els grups que ostentaven el poder i la cultura que s'ha seleccionat i distribuït a les escoles. És necessari desemmascarar els criteris socials i culturals utilitzats per dissenyar els curricula escolars, a quina concepció de societat corresponen, quin tipus de coneixement prioritza, quins mecanismes de control social implica. Això significa una crítica reflexiva per part dels agents educatius, que al seu torn s'afavorisca en l'estudiantat, per desvetlar-ne tot tret racista, sexista o classista explícit i/o implícit, en el currículum ocult, en l'educació i en la societat, per ser conscients de la discriminació que pateixen certs grups, com a pas previ i necessari per a l'acció i la reforma social (Torres, 2011). L'anàlisi crítica dels materials i els continguts curriculars, així com dels mitjans de comunicació i altres productes culturals, són una línia de treball fonamental dins de la pedagogia crítica (Gimeno Sacristán, 2010).

Com entenen els mitjans de comunicació la diversitat? En general, entenen la diversitat com un conjunt d'imatges, veus, paisatges, persones que semblen plurals i diverses, però que són tractades com a desiguals, perquè interpreten la realitat dins del marc d'opinió de l'elit cultural i tenen com a funció emblemàtica l'adquisició i l'ús d'opinions i imatges sobre els grups minoritaris (Bañón Hernández, 1996).

Però quina és la diversitat que mostren els mitjans de comunicació? Vegem-ne alguns exemples:

a) Els mitjans de comunicació marquen allò que és important a la societat $\mathrm{i}$ allò que no ho és. Una forma de fer-ho és ressaltar-ho sobrerrepresentant el fet o les persones als mitjans -aparicions contínues a tot tipus de programes i mitjans- com per exemple la importància màxima del terrorisme (inclús com a primer problema nacional percebut pels ciutadans) i la inseguretat 
social per promoure l'aparició reiterada i magnificada dels cossos d'ordre pública, sobrerepresentats respecte a altres professionals que apareixen als mass media. Però també es poden fer desaparèixer del mapa mediàtic certs col·lectius: discapacitats, minories ètniques, homosexuals, «la tercera edat», «el tercer món»... que estan infrarepresentats als mitjans.

b) Els tipus d'informació i programes diferencien també el tipus de persones:

- Per exemple els gitanos, negres i altres grups culturals en evidents diferències fìsiques són bàsicament protagonistes de noticies i programes sobre conflictivitat social, drogues, delinqüència, per una banda, o bé de noticies i programes de música, d'espectacle i folklore, comèdia.

- On més diversitat ètnica es mostra és a la secció d'esports, sobretot, de futbol.

- A la ràdio la diversitat lingüística també és minimitzada: les modalitats, accents i dialectes són menyspreats i relegats dels programes de més audiència.

- Els discapacitats són notícia relacionada sempre amb la seua discapacitat o per salut mental associada a criminalitat i maltractaments.

- La dóna apareix als programes i noticies d'espectacle, moda, bellesa, salut, món domèstic $\mathrm{o}$, per altre costat, és notícia com a víctima de maltractaments i abusos per part de l'home. En canvi, la seua presència als seccions de política, economia, opinió i portada és pràcticament anecdòtica.

- Les revistes per a dones estan orientades a l'àmbit domèstic: com ser mare, revistes de salut i bellesa, moda, cuina, decoració. L'estil comunicatiu d'aquestes publicacions és intimista, parla amb la lectora com si la tutelara, com si es tractara d'una amiga a la qual donar consells. És, per tant, un to comunicatiu empleat a l'àmbit d'allò privat i que considera els lectors com a sers aïllats, que no tenen relació els uns amb els altres. Aquest enfocament individualista tracta que les dones no desenvolupen una identitat com a col·lectiu i, així, no és fomente la movilització social de gènere (Gallego, 1990).

Kerry Carrington i Anna Bennett (1999) apunten que les noies no són víctimes passives d'una cultura hegemònica de la feminitat, cultura empaquetada, esterilitzada i comercialitzada i que creuen la seua identitat femenina reinterpretant els criteris tradicionals. Per exemple, el maquillatge no té per què ser utilitzat per feminitzar el cos en un sentit unificador. Els maquillatges i els arranjaments proporcionen a les joves tècniques necessàries per desfer i refer l'ajustament sexual, per experimentar amb la seua identitat sexual, per negar el caràcter natural d'un únic estil femení, i per trencar les imatges dicotòmiques de la feminitat i la masculinitat. Per tant, 
els autors demostren que hi ha una lectura molt més lliure i diversificadora de aquestes revistes (i possiblement d'altres productes dels mitjans de comunicació) del que solem pensar. Seria interessant esbrinar com realment els jovens reinterpreten les claus culturals hegemòniques dels mass media, segons les seues circumstàncies històriques, culturals i socials.

Respecte a la infància, el discurs dels mitjans de comunicació s'ha de tornar un bé de consum, dins de la societat capitalista i consumista, això fa que els programes infantils estiguen reforçats per tota una sèrie d'objectes de merchandising que hi fan referència (tovalloles, llibretes, roba de les Tortugues Ninja, Els Simpson). Aquestes pràctiques quotidianes de consum i socials exemplifiquen el postmodernisme cultural del món dels simulacres: un món d'imatges i signes que sols es refereixen a altres imatges i signes, cap dels quals no té un referent concret a la realitat. Els viatges familiars a Disneylandia, els parcs temàtics i d'atraccions de les productores cinematogràfiques $\mathrm{o}$ les pràctiques consumistes necessàries per participar en concursos per veure personatges dels mitjans de comunicació que compleixen aquestes característiques. Així, els nens de la tribu Hill de Tailandia porten gorres dels Bulls de Chicago, a Nova Guinea, samarretes d'Els Simpson o les dones del medi oest nord-americà porten vestits ètnics (Luke, 1999).

- A les revistes sobre maternitat-paternitat i bebès (que reforcen els valors $i$ experiències tradicionals de gènere $i$ classe social) la presència de pares $i$ mares d'altres grups culturals que no siguen el majoritari pràcticament no existeix, excepte quan es tracta de nens d'altres cultures adoptats per occidentals blancs.

d) Estratègies discriminatòries per generar imatges al discurs periodístic són (Bañón, 1996):

- La divisió i la comparació entre un nosaltres caracteritzat sempre de manera positiva i un ells (uns altres) caracteritzats de manera negativa. L'intercanvi i el diàleg intercultural no es donen i si es produeixen són problemàtics.

- Mitigació i excusa: inclou tant els eufemismes com les expressions que justifiquen, encara que fos indirectament, els comportaments discriminatoris o violents cap a les minories ètniques.

- Hipèrbole i ridiculització: utilitzades, sobretot, per desacreditar l'exogrup mitjançant la intensificació de la seua imatge negativa (frívola, ridícula, problemàtica, descontextualitzada).

- Inversió de responsabilitat: de manera que l'exogrup aparega als ulls dels lectors o espectadors com a culpables en lloc de com a víctimes, ja siga 
defensant que els individus de l'exogrup són els racistes, ja afirmant que abusen de la tolerància de l'endogrup (exemple: als titulars s'atribueix als immigrants la culpa dels esdeveniments desagradables que els passen; o s'intensifiquen les suposades conexions entre la immigració i la il·legalitat).

- La negació del racisme: l'endogrup no és racista o ho és molt menys del que es diu, és víctima dels comportaments de l'exogrup, i ofereix la seua ajuda inclús quan l'exogrup no s'ho mereix.

- L'atenuació de la marginació: procés mitjançant el qual s'edulcora la marginació i se n'atenúa la seua gravetat.

- L’homogeneïtzació simbòlica, encarnada per una generalització argumental dels comportaments negatius dels individus de grups marginats: «tots són iguals i sempre fan o diuen el mateix».

- Relativització: dels arguments donats pels reivindicadors de l'exogrup racial minoritari, perquè solen ser falsos, mentiders i poc objectius. Fins $i$ tot es desdramatitza la mort de persones pertanyents a exogrups marginats.

- Focalització/desfocalització: quan es parla dels immigrants i se'ls anomena $\mathrm{il} \cdot$ legals es focalitza en la seua condició jurídica i es desfocalitza la seua condició humana.

Així doncs, aquest discurs és indirecte i implicit, prefereix servir-se de tècniques subtils i estratègies d'intensificació o d'atenuació en lloc de mostrar de forma descarnada les actituds discriminatòries en les quals se substenta. La conseqüència es la creació de tot un món d'estereotips i prejudicis basats en imatges simplificades i deformades de la diversitat:

- Immigrants vénen en desbandada, són una invasió, un perill, són massa nombrosos.

- El gitanos: inexistents, folklòrics, delinqüents, agresius, creen problemes d'higiene o salut pública.

- Els discapacitats: es focatitza en la seua discapacitat i qualsevol aconseguiment és una heroicitat, un mèrit personal i un favor que sembla que la societat fa a aquesta persona (paternalisme).

- Les dones continuen prioritàriament preocupades per qüestions estètiques i domèstiques. La publicitat està aconseguint que una gran part de les dones, amb independència de la seua identitat racial o ètnica, i, cada volta més, de les diferències de classe social i d'orientació sexual, tinguen unes relacions menys lliures i fàcils amb el menjar. És la fam com a pedagogia, com a ense- 
nyament que les dones no poden tenir (o almenys expressar) els seus apetits (el menjar i el sexe estan directament relacionats pel plaer) i que tota la seua relació amb el menjar ha d'estar basat en l'alimentació dels altres (fills i marit) mai com a expressió de la satisfacció del propis plaers (aquesta relació amb el menjar és tota una transgressió). L'home en canvi, sí que pot mostrar el seu voraç apetit, forma part de la seua natura, és fins i tot viril.

I així podríem continuar amb molts altres grups i col·lectius representats als mitjans de comunicació. En conseqüència, la diversitat és entesa com allò que és exòtic, minoritari, problemàtic, marginal, deficitari, assimilable o ridiculitzable. Ser diferent no és un dret, és com un càstig, un estigma. La diferència no és neutral, està impregnada d'ideologia racista que juga amb el relativisme cultural per fer pensar que mostra i ven un món plural on cadascú lliurement tria com vol ser i com vol viure, però que utilitza llenguatges i estratègies persuasives per recordar-nos que no tota diferència és desitjable ni acceptada, en realitat la diversitat i la pluralitat no són recomanables ni convenients socialment i quan no podem negar-la (fent desapareixer la gent), ja que deformem la seua imatge o la problematitzem.

La diversitat es converteix en una moda de mercat, superficial i descontextualitzada sense valor ni poder polític, només un ben de consum, un objecte de disseny, un souvenir turístic. A l'escola, com als mitjans de comunicació, la diversitat es considerada un problema, curiositat, exotisme o dèficit (Giroux, 1996).

\section{Transformant els conflictes, empoderant els sabers locals}

Tota aquesta anàlisi crítica ha d'anar acompanyada d'una acció transformadora, que genere nous espais, noves relacions i noves possibilitats de reconeixement i igualtat. Així, considerem que la diversitat cultural ha de gestionar-se, des de l'àmbit de la psicopedagogia, contemplant la formació des d'un enfocament elicitiu, tal com proposa John Lederach (1995), per a la transformació dels conflictes i l'emancipació de les persones amb l'objectiu de millorar el seu context i reconèixer els sabers locals.

L'enfocament elicitiu parteix de la idea que la formació és una oportunitat principalment per al descobriment, creació i consolidació de models que emergeixen dels recursos presents en cada context particular i respon a les necessitats d'aquest context. El seu leitmotiv podria ser: «Com pescar en els nostres propis estanys». L'èmfasi es posa no només en l'empoderament com a participació per crear models, sinó també en la cerca de recursos i principis en el context cultural mateix. Es comença identificant les necessitats d'un context donat i llavors treballa amb els participants per generar la formació que es correspon amb aquestes necessitats. Per això l'actitud del formador és essencial. Diu Lederach (1995): «jo no tinc la resposta, però podem treballar amb altres en un procés que ens pot ajudar a trobar-la». Es tracta d'empoderar com a procés de validació i construcció d'enforteixes i possibilitats dels recursos des de dintre del propi context i no des de fora d'aquest, generant models adients per a la transformació del conflicte. 
Els participants i el seu coneixement es veuen com la font primària per a la formació, encara que ells al principi no es perceben com a tals. Per coneixement com a recurs, Lederach es refereix als significats moltes vegades implícits però molt rics que la gent dóna al seu propi context. A pesar que el coneixement dels participants té credibilitat i valor, no ho converteix directament en una glorificació del coneixement indígena en si mateix, sinó que suposa confiar en la capacitat i la creativitat dels participants per identificar, anomenar, criticar, crear i recrear models que es corresponen amb les necessitats que experimenten i identifiquen.

El model elicitiu segueix una mica les fases de la investigació-acció:

1. Descobriment. Les activitats que es proposen han de crear una catarsi en els participants per poder pensar sobre el seu coneixement implícit com a recurs de formació. Per exemple: en lloc de fer jocs de rol sobre situacions simulades, convidar els participants a treballar en petits grups a discutir sobre situacions de la vida real que els impliquen directament i utilitzar després la seua pròpia descripció i presentació dels casos com a matèria primera per a la discussió i el desenvolupament posterior de jocs de rol en la formació.

2. Anomenar i categoritzar. El moviment del coneixement implícit a l'explícit és el descobriment. Per a sostenir-ho com a eina de construcció social requereix anomenar-ho, definint i posant nom als seus propis significats. Com a fase del procés de formació, representa l'oportunitat d'identificar i categoritzar amb més claredat els tipus d'activitats, enfocaments i rols que són típics en la forma que la gent té de manejar els conflictes en el seu context.

3. Avaluació. Els participants són convidats no només a redescobrir i descriure el que està present en el seu context sinó també a avaluar el que és beneficiós i el que no (el que funciona i el que no). Una avaluació contextualitzada significa simplement que els participants en un context donat avaluen les seues pròpies accions i comportaments d'acord als criteris i valors d'aquest context, més que jutjar els seus enfocaments d'acord a criteris externs.

4. Adaptar o recrear. En aquesta fase el que se cerca són noves formes de manejar el conflicte, adaptant vells enfocaments en contextos que evolucionen, construint des de les fortaleses, però canviant els aspectes més febles. En aquesta fase, el treball també implica comparar i contrastar amb altres contextos i experimentar en com s'haurien d'afrontar els conflictes. El que comença a emergir és el seu propi model i les seues propostes per a transformar el conflicte.

5. Aplicació pràctica. El procés de formació ha de proporcionar oportunitats per experimentar i redefinir les idees, enfocaments i propostes d'acció que van sorgint. Al principi poden ser situacions simulades, però finalment han d'engegar-se. D'aquesta forma, el cicle d'acció-reflexió-acció, fa que al final del procés de formació els participants se situen en un altre lloc, hagen canviat la mirada i la manera en què transformen conscientment el seu context. 


\section{Activitats de reflexió-acció}

a) Anàlisi de l'experiència: «Una classe dividida». Visionat del vídeo i anàlisi dels elements que es posen en marxa en l'experiència per detectar i eliminar estereotips i prejudicis culturals. A partir de l'anàlisi es fan propostes educatives per a la formació d'actituds interculturals.

b) Fotoparaula: a partir de l'anàlisi crítica del «multiculturalisme de Benetton», segons Henry Giroux (1996), revisem el poder del llenguatge publicitari amb una tècnica de comunicació persuasiva. Aquesta perspectiva comunicativa crítica es posarà al servei del projecte d'investigació-acció participativa en la seua fase de divulgació. Els grups de treball dissenyaran un pla de difusió dels seus projectes que tinga en compte els elements clau perquè es torne una pràctica intercultural i transformadora.

\section{Lectures recomanades}

Giroux, H. (1996): Placeres inquietantes. Aprendiendo la cultura popular, Barcelona, Paidós Ibérica.

McCarthy, C. (1994): Racismo y currículum, Madrid, Morata.

Sales, A. i R. García (1997): Programas de educación intercultural. Bilbao, Desclée de Brouwer.

\section{Recursos web recomanats}

Espais híbrids: www.espaihibrid.com. Pàgina web de la Universitat de Lleida $\mathrm{i}$ dels projectes performatius que fa l'estudiantat de mestre a l'assignatura de processos i contextos educatius amb la professora Gloria Jové.

Red de Escuelas Interculturales: http://www.escuelasinterculturales.eu/.

Centro Aragonés de Recursos para la Educación Intercultural (CAREI): http://carei.es/.

Equipo de orientación educativa y multiprofesional para la equidad educativa de Castilla y León: http://creecyl.centros.educa.jcyl.es/sitio/.

Fundació SER-Gr: http://www.fundaciosergi.org/.

\section{Referències}

Aboud, F. (1994): Children and Prejudice, Massachusetts, Blackwell.

Allport, G. W. (1992): The nature of Prejudice, Massachusetts, Addison-Wesley.

Apple, M. W. (1996): El conocimiento oficial. La educación democrática en una era conservadora, Paidós, Barcelona. 
BAKER, C. (2007): A parents' and teachers'guide to bilingualism, Celvedon, Multilingual Matters.

BAKER, C. (2011): Foundations of bilingual education and bilingualism, Clevedon, Multilingual Matters.

Bañón Hernández, A. M. (1996): Racismo, discurso periodístico y didáctica de la lengua, Almeria, Servicio de Publicaciones de la Universidad de Almería.

Bernstein, B. (1989): Clases, códigos y control I, Madrid, Akal Universitaria.

CARrington, F. i A. BennetT (1999): «Las 'revistas de chicas' y la formación pedagógica de la chica», dins C. Luke (comp.) (1999): Feminismos y pedagogías en la vida cotidiana, Madrid, Morata, 144-159.

Coelho, E. (2007): «How long does it takes? Lessons from EQAOdata on English language learners in Ontario schools», Inspire, The Journal of Literacy and Numeracy for Ontario. Disponible en: www.edu.gov.on.ca/eng/literacynumeracy/ insprie/wequiety/ELL_July.

Coelho, E., J. Oller i J. M. Serra (2013): Lenguaje y aprendizaje en el aula multilingüe. Un enfoque práctico, Barcelona, ICE Universitat de Barcelona-Horsori.

Collier, V. P. i W. P. Thomas (2004): «The astounding effectiveness of dual language education for all», NABE Journal of Research and Practice, 2 (1), 1-20. Disponible en: http://njrp.tamu.edu/2004/PDFs/Collier.pdf.

Cummins, J. (1981): «The role of primary language development in promoting educational success for language minority students», Schooling and Language minority students: A theoretical framework. Evaluation, Dissemination and Assessment Center, Los Angeles, California State University, 51-79.

Cummins, J. (2007): Promoting literacy in multilingual context: Research monograph \#5, Toronto, Ontario Ministry of Education. Disponible en: http://www. edu.gov.on.ca/eng/literacynumeracy/hinspire/research/Cummins.pdf.

Cummins, J. (2008): «Introduction» dins N. Hornberger (Ed.) Encyclopedia of language and education, 2a edició (pp. i-x1), Nova York, Springer.

Eagly, A. H. i S. Chaiken (1993): The Psychology of Attitudes, Orlando, Harcourt Brace Jovanovich.

FishbeIn, M. i I. AJzen (1975): Belief, attitudes, intention, and behavior: An introduction to theory and research, Massachusetts, Addison-Wesley.

Gallego, J. (1990): Mujeres de papel. De iHola! A Vogue: la prensa femenina en la actualidad, Barcelona, Icaria.

Geneese, F. (2008): «Early dual language learning», Zero to Three, 17-23. Disponible en: http://main.zerotothree.org/site/DocServer/ZTT29-1_sep_08-pdf?docID=7242.

Gimeno SACRistán, J. (ed.) (2010): Saberes e incertidumbres sobre el currículum, Madrid, Morata.

Giroux, H. (1996): Placeres inquietantes. Aprendiendo la cultura popular, Barcelona, Paidós Ibérica.

Hewstone, M. i altres (1994) «Cognitive Models of stereotype change: Measurement, development and consequences of subtyping», Journal of Experimental Social Psychology, 30 (6), novembre, 505-526.

Kincheloe, J. L. i SH. R. Steiberg (1999): Repensar el multiculturalismo, Barcelona, Octaedro.

LAMBERT, W. (1984): «Decisiones sobre las lenguas en la enseñanza: consideraciones psicológicas y sociales», dins Husen, T. i S. Opper (1984): Educación Multicultural y Multilingüe, Madrid, Narcea, 118-133. 
Lederach, J. (1995): Preparing for Peace: Conflict Transformation Across Cultures, Syracuse, NY, Syracuse University Press.

Luke, C. (comp.) (1999): Feminismos y pedagogías en la vida cotidiana, Madrid, Morata.

McCARthy, C. (1994): Racismo y currículum, Madrid, Morata.

McLaren, P. i J. L. Kincheloe (eds.) (2008): Pedagogía Crítica. De qué hablamos, dónde estamos, Barcelona, Graó.

NIETO, S. (1992): «We speak in many tongues: Language diversity and Multicultural Education», dins C. DíAz (ed.) (1992): Multicultural Education for the 21st. Century, Washington DC, National Education Association, 112-136.

OKSAAR, E. (1984): «Multilingüismo y multiculturalismo desde el punto de vista del lingüista», dins HuSEN, T. i S. OPPER (1984): Educación multicultural y multilingüe, Madrid, Narcea, pp. 33-59.

OlleR, J. i I. VILA (2008): «El conocimiento de catalán y castellano del alumnado de origen extranjero, tiempo de estancia en Cataluña y lengua inicial al finalizar la enseñanza primaria», Segundas Lenguas e Inmigración en Red, 1, 10-24.

Ponterotto, J. G. i P. B. Pedersen (1993): Preventing Prejudice. A Guide for Counselors and Educators, Califòrnia, SAGE.

Rodrigo Alsina, M. (1999): Comunicación intercultural, Barcelona, Anthropos.

Sales, A. i R. García (1997): Programas de educación intercultural, Bilbao, Desclée de Brouwer.

SiguÁn, M. i W. F. Mackey (1989): Educación y bilingüismo, Madrid, Santillana, Aula XXI/UNESCO.

SiQués, C. (2008): Les aules d'acollida d'educació primària a Catalunya: Descripció $i$ avaluació dels resultats. Tesi doctoral no publicada. Universitat de Girona.

Skutnabb-Kangas, T. i R. Dunbar (2010): «Indigenous children's education as linguistic genocide and a crime against humanity? A global view», Journal of Indigenous Peoples Rights, 1. Disponible en http://www.e-pages.dk/grusweb/55/.

STANGOR, Ch. i altres (1991): «Affective and Cognitive determinants of Prejudice», Social Cognition, 9 (4), 359-380.

Torres, J. (2011): La justicia curricular. El caballo de Troya de la cultura escolar, Madrid, Morata.

Trujillo, F. (2003): «Carta abierta sobre la interculturalidad», Carabela, 54: 167174. Disponible en http://www.ugr.es/ ftsaez/research.htm.

Trujillo, F. (2005). «En torno a la interculturalidad: reflexiones sobre la cultura y comunicación para la didáctica de la lengua», PortaLinguarum, 4, 23-39.

VILA, I. (2012): «La escolarización del alumnado extranjero», Mugak, 59, 7-14. 